SOUTH AFRICAN PRIVATE SECURITY CONTRACTORS ACTIVE IN ARMED CONFLICTS: CITIZENSHIP, PROSECUTION AND THE RIGHT TO WORK

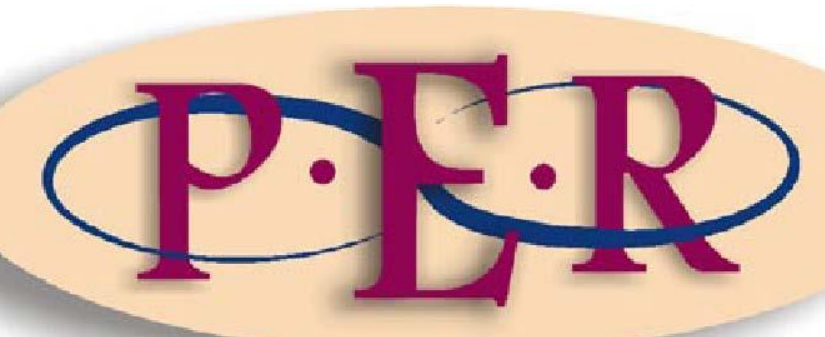

2011 VOLUME 14 No 7

http://dx.doi.org/10.4314/pelj.v14i7.4 


\section{SOUTH AFRICAN PRIVATE SECURITY CONTRACTORS ACTIVE IN ARMED CONFLICTS: CITIZENSHIP, PROSECUTION AND THE RIGHT TO WORK}

\section{S Bosch*}

M Maritz**

\section{Introduction}

Since the end of the Cold War the outsourcing of military and security functions to private security contractors (PSCs) ${ }^{1}$ has reached unprecedented levels ${ }^{2}$ in armed conflicts. In a "world that needs security", ${ }^{3}$ the private security industry is one of the "fastest growing sectors of the economy worldwide", 4 estimated in 2005 to be worth one hundred billion US dollars a year. ${ }^{5}$ This rise of the private security industry should come as no surprise at a time when more than six million highly skilled soldiers were facing demobilisation, and enormous stocks of weapons had fallen into private hands. ${ }^{6}$ Not even the stigma attached to labels like "mercenary", "soldier of fortune" ${ }^{7}$ or "dogs of war" ${ }^{8}$ could quell the growing demand for PSCs to provide a

Shannon Bosch. BA (Hons) LLB (University of Natal) LLM (Cambridge). Senior Lecturer in Law, Howard College, Faculty of Law, University of KwaZulu-Natal; Attorney of the High Court of South Africa. E-mail: bosch@ukzn.ac.za.

** Marelie Maritz. LLB LLM (University of Pretoria). Lecturer in Law, Howard College, Faculty of Law, University of KwaZulu-Natal. E-mail: maritz@ukzn.ac.za.

1 Some authors discriminate between private military contractors, private security contractors and non-lethal service providers (Brooks 2002 www.ipoaonline.org). For the purposes of this article we shall use the generic term "private security contractors" (PSCs) with the caveat that within this group there will be those whose activities might range from active combat or passive defence, through to non-lethal support. We focus our attention on the individuals rather than the corporate entities that PSCs may work for.

2 In 1991 the ratio of military personnel to private contractors active in armed conflicts was estimated at 50:1; by 2003 the ratio exceeded 10:1(Singer Corporate warriors; Singer 2005 people.cas.sc.edu; Lombardi 2004 ABAJ 1). Today, contractors working for the United States (US) Government outnumber US troops in Iraq, and there are reportedly more ex-British SAS troops working as PSCs in Iraq than there are currently serving in the United Kingdom's (UK) SAS force (Amnesty International Date Unknown www.amnestyusa.org; Singer 2006 BJWA 112).

3 Zarate 1998 Stan J Int'l L Law 162.

4 "With some companies employing well beyond 10000 staff...the scale [of the private security industry] is a wholly new phenomenon" (ICRC 2008 www.icrc.org 5).

5 UN Report 2005.

6 Singer 2006 BJWA 106; Frye 2005 Fordham L Rev 2609.

7 Lytton 2006 Or Rev Int'l L 307.

8 Zarate 1998 Stan J Int'l L 75. 
wide spectrum of services, ranging from the non-contentious ${ }^{9}$ to those having "direct lethal consequence". ${ }^{10}$ While they "tend not to openly advertise their more combatlike services" PSCs are clearly not "just running the soup kitchens". ${ }^{11}$ Their clientele includes states; ${ }^{12}$ ruthless dictators; respected private corporations; drug cartels; rebel forces; ${ }^{13}$ international and regional inter-governmental organisations"; ${ }^{14}$ humanitarian non-governmental organisations; ${ }^{15}$ movie directors; and defence lawyers. ${ }^{16}$ PSCs have been deployed in over fifty states, ${ }^{17}$ and in the words of David Milliband (as British Foreign Secretary):

the private military and security company industry is essential, inevitable and international. It is essential because people need protecting in dangerous countries; inevitable, because government cannot deploy protection in all theatres; and international, because the market and suppliers are global. $^{18}$

It also comes as no surprise that PSCs have been a prominent feature on the African continent. Even as we write, reports are emerging from Libya that the ousted Colonel

9 In Afghanistan PSCs (like the US based firm Ronco) were contracted to de-mine the fields so that local villages could till their fields (Faite 2008 www.icrc.org 1). In Iraq PSCs provided security to engineers fixing the sewer system, while their colleagues in Sudan flew in peacekeeping forces (Singer 2006 BJWA 105). In the aftermath of Hurricane Katrina, PSCs guarded against looters and collected the dead (Singer 2006 BJWA 105).

10 PSCs have been hired to "provide combat, operational and logistical support for military operations" (Beyani and Lilly 2001 www.ssrnetwork.net 16); to provide air reconnaissance (as is the case with the US-based firm Airscan (Faite 2008 www.icrc.org 1); to maintain weapons systems; to protect premises and personnel; to train and advise military and police forces (Beyani and Lilly 2001 www.ssrnetwork.net 11); to gather intelligence; to oversee the detention and interrogation of prisoners; to provide security services and conduct crime prevention activities; and in some instances to participate in combat (FCO 2009 www.fco.gov.uk; ICRC 2006 www.icrc.org).

11 Salzman 2008 Int'l L \& Politics 884.

12 During the period 1994-2002 the US Government concluded three thousand contracts with USbased private security firms, at an estimated cost of three hundred billion US dollars (Singer 2006 BJWA 106), and in Iraq the green zone was defended almost exclusively by PSCs (Frye 2005 Fordham L Rev 2610).

13 It is interesting to note that prior to 9/11 PSCs were reportedly employed by two groups linked to al-Qaeda (Singer 2006 BJWA 114).

14 Gillard 2006 IRRC 525; Singer 2006 BJWA 107. Included in this category is the United Nations.

15 Bjork and Jones TWQ 780; Frye 2005 Fordham L Rev 2619. While not many non-governmental organisations (NGOs) are prepared to admit their use of PSCs for fear of losing their funding by being associated with these "dogs of war", those NGOs operating in failed states are nevertheless instructed to "quietly hire" the services of PSCs (Singer 2006 BJWA 109). Many NGOs prefer to hire PSCs rather than to pay off "local security" or local warlords to guarantee their safety (Singer 2006 BJWA 110.) Controversially some NGOs have even been reported to hire PSCs not only for the defence of their staff, but also for the use of PSC snipers (Singer 2006 BJWA 108).

16 Gaston 2008 Harv Int'l L J 227.

17 Including "Afghanistan, Angola, Croatia, Ethiopia, Eritrea, Iraq and Sierra Leone" (Frye 2005 Fordham L Rev 2619; Lytton 2006 Or Rev Int'l L 335).

18 FCO 2009 www.fco.gov.uk 5. 
Gadaffi hired mercenaries from Chad, Nigeria and Sudan to oppose the National Transitional Council in Libya. ${ }^{19}$ As Brookes explains, with

the West reluctant to commit its militaries, the only way that Africa is going to acquire the military capability to end its many conflicts is to contract the services from elsewhere. ${ }^{20}$

In "militarily advanced countries" 21 the excess retired and ex-military personnel ${ }^{22}$ who have had valuable conflict experience and have few civilian employment opportunities provide a vast pool of personnel readily available at "remarkably affordable prices". ${ }^{23}$ Moreover, firms providing PSCs pride themselves on the fact that they "can often undertake operations faster, more cost effectively"24 and with fewer personnel and bureaucratic delays than traditional state armies and UN peacekeepers. ${ }^{25}$ When the genocide in Rwanda was imminent, Executive Outcomes $^{26}$ drew up a business plan that could have had "armed troops on the ground within 14 days", at a cost of six hundred thousand US dollars a day. ${ }^{27}$ In the end the UN relief operation, which cost three million US dollars a day, came too late to save the many hundred thousand victims. ${ }^{28}$ In the words of Mr Beese of UK based Armorgroup, "if you want cost effective solutions to humanitarian emergencies and military overstretch, we're your guys". ${ }^{29}$

19 Reuters Africa 2011 af.reuters.com.

20 Brooks 2000/1 Conflict Trends 33.

21 Zarate 1998 Stan J Int'l L 76.

22 The industry is also a windfall for unemployed ex-servicemen, who stand to earn easily ten times what local security guards are paid in Africa (IRIN 2008 www.irinnews.org). During the Executive Outcomes operation in Sierra Leone a soldier's salary ranged from US\$2000 to US\$13000 per month (Hough 2007 ASR 19).

23 Hiring ex-army personnel from South Africa and Namibia is five or six times cheaper than employing Americans to do the same job, and Southeast Asia and Latin America also provide fertile grounds for hiring PSCs (Brooks 2000/1 Conflict Trends 34; IRIN 2008 www.irinnews.org).

24 When Executive Outcomes were deployed in Sierra Leone their bill came to thirty-six million US dollars as compared with the UN's peacekeepers, which cost three million US dollars a day (Singer 2006 BJWA 111).

25 Wright and Brooke 2007 ASR 108.

26 Executive Outcomes is a private security firm which was based in South Africa and manned mostly by former South African Defence Force members.

27 Singer 2006 BJWA 111.

28 Singer 2006 BJWA 111

29 Carmola 2006 BJWA 170. 
While some hail PSCs as the world's future peacekeepers ${ }^{30}$ acting as a "stabilising force", ${ }^{31}$ others challenge their legitimacy, maintaining that they are no more than the 21st century's mercenaries, "recycled", 32 "repackaged", ${ }^{33}$ who come armed with a business model, "publicly listed companies", 34 corporate websites, and slick corporate identities. ${ }^{35}$ Admittedly, the private security boom has motivated some previously mercenary-type operatives to re-invent themselves as supposedly legitimate private security companies. ${ }^{36}$ Whichever view one might hold, one thing is certain, the "existing international legal regimes" do not even "contemplate the existence" of PSCs, leaving PSCs in the "same grey area as the unlawful combatants detained at Guantanamo Bay". 37

Those who adhere to the view that PSCs are modern-day mercenaries would argue that we need only look to the two international treaties dealing with the eradication of mercenarism proposed by the United Nations ${ }^{38}$ and the Organisation of African Unity (OAU), ${ }^{39}$ for guidance on how to approach the issue of PSCs. If this is a compelling position one would expect that the majority of states who are party to these two conventions would have domestic legislation in place regulating the activities of PSCs. Instead what we find is that only one (Italy) of the fifty-four states that have ratified either the UN Mercenary Convention or the OAU Mercenaries Convention has taken any steps at a domestic level to ban or regulate the activities of PSCs, ${ }^{40}$ which we would argue supports the view that the label "mercenary" and its

30 Lilly 2000 www.unidir.org 58. Cameron 2006 IRRC 863.

31 Lytton 2006 Or Rev Int'l L 313.

32 Zarate 1998 Stan J Int'I L 77 and 91.

33 Salzman 2008 Int'l L \& Politics 876.

34 Palomba 2009 www.e-IR.info 1.

35 Singer 2006 BJWA 105; Abrisketa 2007 FRIDE Comment 2; Cullen 2000 Conflict Trends 36.

36 Bjork and Jones 2005 TWQ.

37 Singer 2006 BJWA 116; Frye 2005 Fordham L Rev 2637.

38 UN Mercenary Convention; Fallah 2006 IRRC 603.

39 The OAU Mercenary Convention entered into force in on 22 April 1985 and to date only 30 Members of the African Union have ratified the convention.

40 At the moment only South Africa and the United States (US) (two of the major suppliers of PSC personnel and management) have any domestic legislation aimed at PSCs (Frye 2005 Fordham $L$ Rev 2645). The UK (another major source of PSCs) has drafted a Green paper but has yet to draft legislation on the subject. At the moment it appears the UK is favouring the regulatory framework which was adopted by the US (Walker and Whyte 2005 ICLQ 667). The other major suppliers of "management and operational personnel" for PSCs come from "France; Israel; Central and Eastern Europe", and as yet only Italy has passed domestic legislation aimed at regulating PSCs (Walker and Whyte 2005 ICLQ 651). 
accompanying legal regimes are not particularly useful when dealing with the issue of PSCs. ${ }^{41}$

South Africa has arguably the most aggressive regime of domestic legislation aimed at regulating the activities of PSCs, which is not surprising after it inadvertently found that it was a major exporter of PSCs ${ }^{42}$ in the post-apartheid era. The Regulation of Foreign Military Assistance Act 15 of 1998 (hereafter the FMA) entered into force in 1998 and was the government's hard-line response after Executive Outcomes made headlines around the world for their intervention in Sierra Leone in 1995. Eight years later, in response to concerns that the $F M A$ was proving unworkable, the government promulgated the Prohibition of Mercenary Activities and Regulation of Certain Activities in the Country of Armed Conflict Act 27 of 2006 (hereafter the PMA). While the PMA received the necessary presidential assent in November 2007, over three years later it has yet to achieve the presidential proclamation necessary for the PMA to repeal the FMA and enter into force.

South Africa appears to be alone in its mission to adopt such an aggressive stance towards regulating the private security industry. It is unlikely that a few pieces of domestic legislation, like those adopted by South Africa, will have any noticeable effect on the presence of PSCs as a feature of current and future armed conflicts. The unique situation posed by South Africa's legislation poses some interesting questions which we will explore. We begin by looking at the role played by PSCs in armed conflicts, and the status afforded them by international humanitarian law $(\mathrm{IHL})$. We turn then to the issue of prohibited mercenarism, investigating if the actions of PSCs serve to group them with mercenaries (as defined by Additional Protocol I [AP I] and the two international Mercenary Conventions). ${ }^{43}$ We then shift our focus to the South African situation and discuss the ambit of application of both the FMA and its proposed successor, the PMA, exploring how these two pieces of legislation measure up to international law obligations regarding mercenarism. We discuss whether or not it is likely that the FMA and the proposed PMA might be successfully used to prosecute PSCs, and what penalties PSCs might face. Lastly

41 Frye 2005 Fordham L Rev 2642.

42 Holmqvist 2005 SIPRI 50.

43 OAU Mercenary Convention and UN Mercenary Convention. 
we consider the constitutional challenges which might emerge as the FMA, PMA and the proposed amendment to section 6 of the South African Citizenship Act (Bill B17 of 2010$)^{44}$ threaten the constitutionally protected rights of South African PSCs to practice a profession and enjoy citizenship.

\section{The international humanitarian law status of PSCs in armed conflicts ${ }^{45}$}

International Humanitarian Law (IHL) is the body of law applicable in situations of armed conflict. ${ }^{46} \mathrm{IHL}$ classifies all those who find themselves in a situation of armed conflict into specific legal categories. Nobody who finds themselves in an armed conflict "can be outside of the law". ${ }^{47}$ They are either combatants (or authorised to accompany the armed forces), or they are civilians. There are many legal consequences which flow from this initial classification. Those labelled civilians, for example, are protected from the hostilities, provided they refrain from participating directly in the hostilities, ${ }^{48}$ while combatants are authorised to partake in hostilities and cannot be prosecuted for their participation (provided they observe the laws of war). ${ }^{49}$ With PSCs fast outnumbering traditional armed forces in present day armed conflicts there is an urgent need for IHL to address the question of their status and to assess their legal right to participate directly in hostilities. ${ }^{50}$

While IHL treaties and international human rights law are binding on PSCs operating in situations of armed conflict, ${ }^{51} \mathrm{IHL}$ as it stands makes no reference to PSCs as such. This leaves military commanders with the unenviable task of assessing the status of PSCs on a case-by-case basis, reaching conclusions based largely on the specific functions that the particular PSCs are performing. ${ }^{52}$ When one reviews the list of activities that PSCs have been hired to perform, it is clear that while PSCs are

44 Portfolio Committee on Home Affairs 2010 www.pmg.org.za.

45 For a more extensive discussion of the IHL status of PSCs see Bosch 2007 ASR.

46 Fleck "Introduction" xi.

47 Pictet Geneva Conventions 51.

48 Gasser "Protection of the Civilian Population" 210.

49 Ipsen "Combatants and Non-combatants" 80.

50 Cameron 2006 IRRC 582.

$51 \mathrm{IHL}$ is unusual in that it applies "to all individuals who find themselves in a territory in which there is an armed conflict (international or non-international), whether they are state or non-state actors" (Cameron 2007 www.baselgovernance.org; Singer 2006 BJWA 115; ICRC 2008 www.icrc.org 39).

52 ICRC 2008 www.icrc.org 14. 
not typical uniformed combatants in the way that IHL understands that term, they are also not your regular civilians. When one considers that states make extensive use of PSCs, it is worth considering whether PSCs are effectively incorporated into the armed forces by way of contractual agreements. ${ }^{53}$

In terms of IHL there is certainly no legal obstacle to a state's promulgating domestic legislation endorsing the incorporation of PSCs into the armed forces. ${ }^{54}$ All that $\mathrm{IHL}$ requires of states is that they ensure that these PSCs distinguish themselves from civilians, carry their arms openly, observe IHL, are subject to command responsibility and internal disciplinary systems, and that the opposition forces are notified of their incorporation. ${ }^{55}$ However, if one looks closely at state practice, it is evident that states do not consider commercial contracts, on their own, to be sufficient to incorporate PSCs into the ranks of the armed forces. In fact, the majority of states making use of PSCs go to great lengths to emphasise that they are merely civilian contractors, authorised to accompany the armed forces. ${ }^{56}$ Very often PSCs are hired precisely to circumvent "national laws that would prevent [states] from sending their own armed forces" into a conflict. ${ }^{57}$ Some writers suggest that the unspoken motive behind a state's use of PSCs to "do their dirty work" is the goal of avoiding "direct legal responsibility" for their actions. ${ }^{58}$ For the most part, then, while states that hire PSCs might be responsible for their actions, the PSCs themselves will not be able to claim IHL combatant status (as persons incorporated into the state's armed forces)

53 Gillard suggests that the following factors might indicate affiliation to the armed forces of a state: "whether they have complied with national procedures for enlistment or conscription, where they exist; whether they are employees of the department of defence; whether they are subject to military discipline and justice; whether they form part of and are subject to the military chain of command and control; whether they form part of the military hierarchy; whether they have been issued with the identity cards envisaged by the Third Geneva Convention or other forms of identification similar to those of 'ordinary' members of the armed forces; and whether they wear uniforms" (Gillard 2006 IRRC 533).

54 Gillard 2006 IRRC 534; Cameron 2007 www.baselgovernance.org 3; a 4A(2) Geneva Convention III (GC III).

55 Article 4A(2) GC III; a 43(3) Additional Protocol I (AP I).

56 Department of Defence 2005 www.dtic.mil.

57 Cameron 2007 www.baselgovernance.org.

58 Abrisketa 2007 FRIDE Comment 2. We would argue that if this is indeed their motivation, then these states have been ill advised, since state responsibility may be invoked as a result of the contract alone, giving rise to liability on the part of states hiring PSCs (Ipsen "Combatants and Non-combatants" 69; Cameron 2006 IRRC 584; Gillard 2006 IRRC 533 and ICRC 2008 www.icrc.org 11). For a more detailed discussion of the issue of state responsibility see Bosch 2008 CILSA; Gillard 2005 www.icrc.org 8. 
because of the deliberate refusal by states to officially incorporate them into their armed forces.

There is another category of personnel which $\mathrm{IHL}$ recognises and which, although not enjoying full combatant privilege, is nevertheless very closely aligned to the armed forces of a state, much as PSCs are contracted by states. This IHL category is termed "persons accompanying the armed forces". 59 These personnel provide specialist expertise ${ }^{60}$ but are not fully fledged members of the armed forces, they do not wear uniform, they are not armed, and they are not permitted to engage in hostilities in any direct way. ${ }^{61}$ Within the category of "persons accompanying the armed forces" we find civilian members of military aircraft crews; war correspondents; supply contractors; reconstruction contractors; members of labour units; and those providing services for the welfare of the armed forces. ${ }^{62}$ Many of these functions are in fact being performed by today's PSCs. These essentially civilian contractors retain their civilian status, despite the fact that their assistance is used to win a military advantage over the opposition. ${ }^{63}$ Despite the fact that IHL views these "persons accompanying the armed forces" as civilians, they do enjoy one privilege normally reserved for the armed forces: that of prisoner of war (POW) status if detained for security reasons. ${ }^{64}$ For this reason "persons accompanying the armed forces" carry with them an identity card which confirms their status and POW privilege. ${ }^{65}$ While PSCs might be providing services similar to the services provided by those who traditionally accompany the armed forces, there are two obstacles to PSCs' claiming this IHL status. Firstly, PSCs do not carry the recognised identification cards reflecting this status, and secondly they would have to prove that their actions did not amount to direct participation in hostilities. A further difficulty for PSCs operating in armed conflicts of an internal nature is that this IHL category of "persons accompanying the armed forces" applies only to "international armed

59 Article 4A(4) GC III; Walker and Whyte 2005 ICLQ 675.

60 When one looks at the tasks normally performed by those accompanying the armed forces it is clear that the drafters of GC III did not intend to include in this group "persons carrying out activities that amount to direct participation in hostilities" (Gillard 2006 IRRC 537).

61 Ipsen "Combatants and Non-combatants" 95.

62 Article 4A(4) GC III.

63 Parrish 2007 www.polisci.wisc.edu.

64 Article 4A(4) GC III.

65 Ipsen "Combatants and Non-combatants" 95; a 4A(4) and Annex IV A GC III. 
conflicts". Moreover PSCs would need to provide their services to the armed forces, not merely the state, in order to qualify for this status. ${ }^{66}$ As for the issue of identification, it is accepted that when the Geneva Convention drafters included the provision regarding the identity card for those accompanying the armed forces it was agreed that

possession of one was a supplementary safeguard for the person concerned, but not an indispensable prerequisite for being granted prisoner of war status. ${ }^{67}$

Having said this, it is clear that where PSCs are directly participating in hostilities or where they are hired by non-state actors without any affiliation to the armed forces, ${ }^{68}$ they will not be able to claim this IHL status.

If PSCs are not incorporated into the armed forces or are unable to satisfy the requirement of "persons accompanying the armed forces" they will, by default, be classified as civilians. This default position is the result of a presumption that exists in IHL that where there is "doubt a person shall be considered to be a civilian". 69 Those PSCs who fall into this default position are subject to one very important restriction: with the exception of the levée en masse, civilians are not permitted to participate directly in hostilities. ${ }^{70}$ Provided they do not take part in the hostilities, PSCs are to be respected, shielded from attack, and may not be "taken prisoner without sufficient reason". ${ }^{71}$ Civilians who take an active part in hostilities, in violation of this prohibition, open themselves to attack from the opposition acting in self defence during and for such time as they continue to actively participate in hostilities. $^{72}$

It is "safe to conclude that the majority of PSCs hired by states" will fall into the IHL category of the ordinary citizen. ${ }^{73}$ Admittedly, PSCs are inherently a different category of civilian from those envisaged in the IHL conventions. They are clearly not

66 ICRC 2008 www.icrc.org 36.

67 Gillard 2006 IRRC 537.

68 Cameron 2006 IRRC 593.

69 Article 50(1) $A P I$, which defines a civilian as any person who is not a combatant.

70 Gasser "Protection of the Civilian Population" 210; a 27(1) Geneva Convention IV (GC IV).

71 Article 27(1) Geneva Convention I (GC I); a 51(2) AP I; a 13(2) Additional Protocol II (AP II).

72 Article 51(8) AP I; ICRC 2008 www.icrc.org 14.

73 Gillard 2005 www.icrc.org 6; ICRC 2008 www.icrc.org 36. 
wholly innocent civilians going about their daily routine, caught in the crossfire. They have, after all, deliberately chosen to place themselves in the line of fire in an attempt to have an impact on the outcome of hostilities. PSCs are for the most part armed, a fact which begs the question: if they are essentially civilians, when are they permitted to use their weapons without being seen to be participating directly in hostilities? To this end, PSCs will need to familiarise themselves with the ICRC's Interpretive Guide $^{74}$ as to what actions might amount to "direct participation in hostilities". Singer, ${ }^{75}$ in his research into PSCs, provides a helpful categorisation, using the analogy of a spear, to illustrate the various levels of involvement which PSCs might undertake in armed conflicts:

At the tip of the spear are the "military provider firms that provide implementation and command services", in the mid section are the "military consultancy firms which provide advisory and training services", and lastly are the "military support firms which provide non-lethal aid and assistance". ${ }^{76}$

Clearly the most problematic groups, in so far as the prohibition against direct participation in hostilities is concerned, are those that occupy the tip of the spear. At the tip of the spear we find those PSCs who are employed to undertake "targeted killings"; 77 operate high-tech weapons; or use computers to direct a weapon to strike a target remotely, ${ }^{78}$ and it has always been held that these actions amount to direct participation in hostilities ${ }^{79}$. The first conclusion we can draw then is that if PSCs are for the most part considered to be civilians, then whether or not they are found to be in violation of the prohibition against direct participation in hostilities will depend on the particular role which they play in the armed conflict.

It is uncontroversial that $\mathrm{IHL}$, as it stands at present, permits the use of civilian contractors in "a civil police role in occupied territory", ${ }^{80}$ and in carrying out this type of function PSCs "might be authorised to use force when absolutely necessary to

74 ICRC 2009 www.icrc.org.

75 Baker and Gumedze 2007 ASR 3.

76 Baker and Gumedze 2007 ASR 3.

77 Policy Brief 2008 www.hpcr.org 9.

78 Cameron 2007 www.baselgovernance.org.

79 Cameron 2007 www.baselgovernance.org.

80 Elsea, Schwartz and Nakamura 2004 www.opencrs.com. 
defend persons or property". 81 Likewise, PSCs employed as guards for reconstruction companies would be entitled to use force in self defence and to "protect the facilities they are guarding, as long as they did so in a defensive manner and employed no more force than was strictly necessary". ${ }^{82}$ PSCs carrying out "support and logistical activities" which are normally carried out by civilians, like "catering, construction and maintenance of bases", will not be considered to be participating directly in hostilities. ${ }^{83}$ Similarly PSCs employed to conduct checkpoint searches would not violate the prohibition against direct participation in hostilities, provided they were not authorised to use a weapon. ${ }^{84}$ Moreover, both Faite ${ }^{85}$ and the ICRC's ${ }^{86}$ authoritative commentary conclude that "foreign advisers and military technicians" are never said to participate directly in hostilities.

In some instances it will be the PSC's location that will determine his or her IHL status. So, for example, it is uncontroversial that PSCs carrying out civilian guarding duties at purely civilian sites or otherwise protected sites like schools, churches and hospitals could never be said to be participating directly in hostilities. ${ }^{87}$ The same will not be true of PSCs who position themselves at purely military objectives like an armoury or command centre belonging to the opposition forces. ${ }^{88}$ The presence of PSCs at a legitimate military target "aids the war effort and constitutes direct participation in hostilities". ${ }^{89}$ Much like workers in a munitions factory, while the civilian workers and guarding PSCs may not be personally targeted (because they retain their civilian protection from attack), the military objectives at which they are situated remain open to attack. ${ }^{90} \mathrm{IHL}$ does not "draw a distinction between offensive or defensive operations". Consequently there is no guarantee of protection by claiming that the PSCs are merely performing guard duties. The truth of the matter is

81 Elsea, Schwartz and Nakamura 2004 www.opencrs.com.

82 Dworkin 2004 www.crimesofwar.org. What analysts have learnt from the conflict in Iraq is that "a situation can go from passive defence to active offence very quickly in an unstable environment", and the distinction between "combat and non-combat operations is often artificial" (FCO 2002 www.fco.gov.uk para 10). Ipsen expresses the opinion that "technically armed security staff are civilians, like the contractors working with reconstruction" (Bjork and Jones TWQ 782).

83 Cameron 2006 IRRC 588-589.

84 Policy Brief 2008 www.hpcr.org 9.

85 Faite 2008 www.icrc.org 4; Salzman 2008 Int'l L \& Politics 882.

86 Sandoz, Swinarski and Zimmermann ICRC Commentary 579.

87 Articles 51(1), 51(2) AP I; Faite 2008 www.icrc.org 8.

88 Parrish 2007 www.polisci.wisc.edu 13; Human Rights Watch 2003 www.hrw.org.

89 Parrish 2007 www.polisci.wisc.edu 13.

90 Faite 2008 www.icrc.org 8. 
that if they are deployed at a military objective they are participating in hostilities. ${ }^{91}$ Having said that, a commander is always expected to be aware of the principle of proportionality in justification for an attack, and he or she should thus exercise greater caution if a site is inhabited predominantly by civilian PSCs. ${ }^{92}$

If PSCs located at civilian sites are not considered to be participating in hostilities and PSCs located at military objectives are classified as participating in hostilities, what then of PSCs guarding dual-use sites like communications networks, power sources, oil refineries, transportation infrastructure (ports and airports), and the like facilities which serve both the civilian population and the armed forces? In terms of $\mathrm{IHL}$ there is a clear presumption in favour of protected status for dual-use sites. ${ }^{93}$ While that presumption persists it seems intuitively right that PSCs guarding dualuse sites be afforded greater protection than those located at single-use military installations, in other words transferring the presumption of protected status (in respect of the site) to PSCs guarding the site and granting them civilian status until such time as the status of the installation can be determined to be offering any military advantage. To this end it would be useful if IHL drew some distinction between defensive and offensive guarding. At the moment AP I states only that an "attack means any act of violence... whether in offence of defence" (article 49(1)). This leaves PSCs who are defensively guarding dual-use sites in an unenviable position. In terms of IHL their defensive guarding would amount to an "attack" (thereby constituting unlawful direct participation in hostilities), whether the site is determined to be a military objective or not. ${ }^{94}$

So, in terms of IHL, PSCs may, depending on their location and particular activities, be assigned differing status. For the most part PSCs will not be able to claim combatant status under IHL because of the deliberate refusal by states to officially incorporate them into their armed forces, although in law there is no legal obstacle to states passing legislation to incorporate PSCs into their traditional armed forces. As

91 Gillard 2005 www.icrc.org 7.

92 Human Rights Watch 2003 www.hrw.org; Oeter "Methods and Means of Combat" 163.

93 Article $52 A P$ / states: "in case of doubt whether an object which is normally dedicated to civilian purposes, such as a place of worship, a house, or other dwelling or a school, is being used to make an effective contribution to military action, it shall be presumed not to be so used".

94 Gillard 2006 IRRC 540. 
for claims that they are similar to civilian contractors or "persons accompanying the armed forces", PSCs might be classified as such provided they could overcome the requirement of carrying a recognised identification card reflecting this status, and prove that they were not participating directly in hostilities. This option will not, however, be available to PSCs who are hired by non-state actors without any affiliation to the armed forces. ${ }^{95}$ As for claims that they are civilians, this would be sustainable provided they were only guarding civilian locations and refrained from any direct participation in hostilities. As soon as they are located at single-use military sites their presence at a legitimate military target would render them vulnerable to attack. Those PSCs found guarding dual-use sites would be afforded civilian status until such time as the status of the installation is deemed to offer any military advantage and for so long as they refrained from using force.

\section{PSCs: mercenaries by another name?}

When private security companies like Executive Outcomes undertake an assignment in mineral-rich territories and are paid by way of mining concessions, many commentators conclude that they are really just mercenaries by another name. In this section we aim to unpack the IHL and treaty law definition of a mercenary in the hope of either confirming or dismissing these claims.

The oldest treaty reference to mercenaries can be found in the Hague Convention of $1907^{96}$ that was drafted in response to concerns that the activities of mercenaries would compromise the right of "post-colonial states to self determination". ${ }^{97}$ While Hague $V$ does not criminalise mercenary activities, it does stipulate that neutral states are to refrain from assisting mercenaries or permitting the recruitment of mercenaries on their territory. ${ }^{98}$ Having said this, however, nothing in Hague $V$ prohibits mercenaries from passing through a neutral state's territory. ${ }^{99}$ It was only in

95 Cameron 2006 IRRC 593.

96 Hague $V$.

97 Fallah 2006 IRRC 599. In short the provisions in Hague $V$ prevent the recruitment or organising of combatants in neutral territories (a 4), while permitting individuals to cross the border and offer their services to the belligerent party without negating that state's neutral status (a 6).

98 Article 4 Hague $V$.

99 Article 4 Hague $V$. 
1977 that African delegates to the drafting negotiations of $A P$ / championed the inclusion of article 47, which sought to deny mercenaries the privileges associated with lawful combatant status. ${ }^{100}$ The inclusion of article 47 was met with considerable resistance and some very influential states (most notably the US) refused to ratify $A P$ $I$ citing this very provision as its reason for not ratifying it. ${ }^{101}$ Some academics maintain that the poor state response to article 47 of $A P I$, alongside the poor ratification levels and very apathetic enforcement of the UN and OAU Mercenary Conventions, ${ }^{102}$ has led some to conclude that the conventions are indicative of "anti-customary law". ${ }^{103}$ Henckaerts ${ }^{104}$ concedes that while the definition of a mercenary (as set out in $A P$ / article 47) is problematic, the principle that "mercenaries do not have the right to combatant or prisoner-of-war status" is considered to have achieved customary law status applicable in international armed conflicts. Whether it is considered custom or not, the application of $A P$ I article 47 is certainly limited to international armed conflicts, leaving unanswered the issue of how one defines a mercenary in non-international armed conflicts. ${ }^{105}$ If controversy surrounds the customary status of provisions which prohibit mercenaries, how much more so can the case be made against the international criminalisation of PSCs ${ }^{106}$ which, we contend, will probably not satisfy the definitional requirements of mercenary status.

Despite UN General Assembly resolutions ${ }^{107}$ stating that "mercenaries are outlaws"108 and "punishable as criminals", ${ }^{109}$ and the 1970 General Assembly Declaration on Principles of International Law Concerning Friendly Relations and Cooperation amongst States, which claims that "states have a duty to refrain from

100 Gaston 2008 Harv Int'l L J 232.

101 Kwakwa 1990 HICLR 68.

102 OAU Mercenary Convention and UN Mercenary Convention.

103 Salzman 2008 Int'I L \& Politics 878-879; Abrisketa 2007 FRIDE Comment 7; Zarate 1998 Stan J Int'I L 78, 120 and 134; Beyani and Lilly 2001 www.ssrnetwork.net 5. Noticeably absent from the UN Mercenary Convention is any substantial support from EU States (barring Italy and Belgium) and G8 states (barring Italy).

104 Henckaerts and Doswald-Beck 9 (eds) Customary International Humanitarian Law 108.

105 Gillard 2006 IRRC 4.

106 Salzman 2008 Int'l L \& Politics 879.

107 The Security Council has also on occasion issued resolutions aimed at specific incidents involving mercenaries in the 1960s, demanding "their immediate withdrawal" from foreign territories (SC Res. 289).

108 GA Res 2625.

109 GA Res 3103. 
organising armed groups, including mercenaries, for incursion into the territory of another state", ${ }^{110} \mathrm{IHL}$ has had little success in criminalising mercenary activities. To date mercenarism alone is still not a prosecutable offence under IHL. At best, mercenaries are denied combatant and POW status. ${ }^{111}$ For the most part this omission on the part of IHL can be attributed to the fact that the IHL definition of a "mercenary" is widely regarded as unworkable, ${ }^{112}$ "if not impossible". ${ }^{113}$ Even if the definition were workable, there are still no "monitoring or enforcement mechanisms...at the international law level" to police mercenary activities. ${ }^{114}$ Moreover, mercenarism per se does not feature as a prosecutable offence under the Rome Statute of the International Criminal Court, ${ }^{115}$ unless the definition of aggression includes "some crime of mercenarism itself". ${ }^{116}$ This said, it must be remembered that all individuals, be they official armed forces, mercenaries, or PSCs are bound by the rules of IHL and can face individual criminal responsibility for war crimes. $^{117}$

At present IHL defines a mercenary

as any person who (in the context of an international armed conflict):

(a) is specially recruited locally or abroad in order to fight in an armed conflict;

110 GA Res 2625.

111 Once individuals are identified as mercenaries they no longer have the right to claim combatant and prisoner of war status (a $47 A P$ ). Consequently they may not be immune from prosecution for participating in hostilities (as is the case with any civilian found participating directly in hostilities), and at best they can claim the minimum fundamental guarantees enshrined in a 75 AP I (Fallah 2006 IRRC 606, Beyani and Lilly 2001 www.ssrnetwork.net 15). The Geneva Convention dealing with POW status (GC III) does not make any mention of mercenaries, a fact which has led to speculation that the convention drafters "intended to confer full POW status on mercenaries" (Frye 2005 Fordham L Rev 2526).

112 Cameron 2007 www.baselgovernance.org and Cameron 2006 IRRC 578. Fallah cites the case of "Bob Denard who was convicted under French Law for 'belonging to a gang who conspired to commit a crime', for his part in aiding rebels to attempt a coup in the Comores Islands". A more mercenary act one can hardly imagine, and yet the anti-mercenary conventions were not utilised to effect a prosecution (Fallah 2006 IRRC 611).

113 Frye 2005 Fordham L Rev 2637.

114 Frye 2005 Fordham L Rev 2638.

115 Fallah 2006 IRRC 610. Having said that, mercenary status can be used by the prosecution in arguing aggravating circumstances at the time of sentencing (Frye 2005 Fordham $L$ Rev 2632).

116 Frye 2005 Fordham L Rev 2632. It is common knowledge that the US concludes bilateral treaties with states where its soldiers operate to ensure their immunity from prosecution. What is more interesting is that the US sought this exception in respect of the PSCs operating in Afghanistan and Bosnia (Walker and Whyte 2005 ICLQ 687).

117 Gillard 2006 IRRC 7. When news of the abuses at Abu-Ghraib broke, it was determined that PSCs (from CACl and Titan) had been hired to perform interrogations, yet the only prosecutions that resulted were in respect of US soldiers (Singer 2005 people.cas.sc.edu). 
(b) does, in fact, take a direct part in the hostilities;

(c) is motivated to take part in the hostilities essentially by the desire for private gain and, in fact, is promised, by or on behalf of a Party to the conflict, material compensation substantially in excess of that promised or paid to combatants of similar ranks and functions in the armed forces of that Party;

(d) is neither a national of a Party to the conflict nor a resident of territory controlled by a Party to the conflict;

(e) is not a member of the armed forces of a Party to the conflict; and

(f) has not been sent by a State which is not a Party to the conflict on official duty as a member of its armed forces. ${ }^{118}$

Given that all six criteria have to be fulfilled cumulatively, the threshold is difficult, if not impossible, to cross. If individuals could be shown to have satisfied all six criteria they might face prosecution, not for mercenarism per se, but for participating directly in hostilities without authorisation, much as civilians will face prosecution as unlawful combatants.

These definitional difficulties are not peculiar to IHL. They have also beleaguered the two international treaties that deal with mercenarism: the UN Mercenary Convention $^{119}$ and the OAU Mercenary Convention. ${ }^{120}$ In adopting substantially similar definitions, these conventions unwittingly took on board the problems which $\mathrm{IHL}$ had faced in dealing with mercenaries. The OAU Mercenary Convention was adopted in Libreville on 3 July 1977 and came into force on 22 April 1985. To date only thirty members of the African Union have ratified the convention. Four years later the UN adopted the UN Mercenary Convention, which took a further twelve years before it entered into force on 20 October 2001. To date it has been ratified or acceded to by only thirty-two countries. Notably absent are the Security Council's five permanent members and the world's major employers and suppliers of PSCs (the US, the UK and SA). Even at the drafting stage there was vehement resistance on the part of Western states to proposals that both $A P$ I and the UN Mercenary Convention include penalties for states making use of mercenaries. ${ }^{121}$

118 Article 47(2) AP I.

119 UN Mercenary Convention.

120 Infamously, the OAU Mercenary Convention failed to avert a coup attempt in Equatorial Guinea in 2004 largely due to its definitional difficulties (Gumedze 2007 ASR 22).

121 Gaston 2008 Harv Int'I L J 232. 
While the UN Mercenary Convention applies to all conflicts (both internal and international), ${ }^{122}$ which is an extension of $A P$ /'s international application, its definition excludes $A P$ I's requirement (b), that the individual must in fact take part in hostilities. $^{123}$ The UN Mercenary Convention includes within its ambit those who "attempt or recruit, use, finance or train individuals who fulfil these criteria as well as their accomplices". ${ }^{124}$ The net result is that "no state may use mercenaries under any circumstances" and captured mercenaries may be extradited under the convention. ${ }^{125}$ Rather surprisingly the UN Convention does not impose a

total ban on mercenaries; it only prohibits those activities aimed at overthrowing a government, undermining the constitutional order of a state or undermining the territorial integrity of a state. ${ }^{126}$

It seems that "it is the mercenary's fighting cause that seems to matter to the UN, not the mercenary as a fighter". ${ }^{127}$ Without any real "monitoring and enforcement mechanisms" it is not surprising that as yet no one has ever faced prosecution pursuant to the convention. ${ }^{128}$ Even in the few instances where there were relatively clear cases of mercenary activity (like the coup attempt in Equatorial Guinea), those prosecuting the violations chose to charge the accused individuals with firearms and immigration violations ${ }^{129}$ rather than mercenarism per se. Perhaps it is more alarming still that states who are party to the convention (like Congo-Brazaville, DRC, Nigeria, Angola, and most recently Libya) have either made use of mercenaries or "permitted or benefited from mercenary trade since ratifying the UN Mercenary Convention", ${ }^{130}$ reinforcing the academic opinion that the convention is actually indicative of "anti customary law". ${ }^{131}$

122 Frye 2005 Fordham L Rev 2630.

123 Fallah 2006 IRRC 609.

124 Articles 2, 3 UN Mercenary Convention.

125 Article 10 UN Mercenary Convention.

126 Articles 1(2)(a)(i) and (ii) UN Mercenary Convention; Beyani and Lilly 2001 www.ssrnetwork.net 24.

127 Kritsiotis 1998 Fletcher F World Aff 14.

128 Frye 2005 Fordham L Rev 2642.

129 Clapham 2006 IRRC 513.

130 Frye 2005 Fordham L Rev 2642.

131 Frye 2005 Fordham L Rev 2642, Abrisketa 2007 FRIDE Comment 7. 
As for the OAU Mercenary Convention, it mimics the IHL definition of a mercenary as set out in $A P I$, save for the fact that the compensation promised need not be in excess of that paid ordinary combatants (as set out in AP I article 47 (2)(c)). "Monetary gain of any amount" is sufficient under the OAU Mercenary Convention. ${ }^{132}$ The scope of application of the OAU Mercenary Convention is limited to "those fighting against a process of self determination, stability or the territorial integrity of another [OAU] state". ${ }^{133}$ This leaves the door open to AU states to use "mercenaries" in other capacities (i.e. "in internal conflicts or to violate the sovereignty of nonmember states"). ${ }^{134}$ Like the UN Mercenary Convention, "the recruitment, use, financing and training of mercenaries" are prosecutable offences, provided the states party to the convention have implemented domestic legislation to this effect. ${ }^{135}$ On the whole, the Convention's obligations have been largely ignored by AU states who are party to the convention ${ }^{136}$ with none having promulgated legislation, despite the fact that it was African states who pressed for the inclusion of article 47 in $A P I^{137}$

However problematic these definitions of a "mercenary" might be, they nevertheless remain the international benchmark for assessing the behaviour of those PSCS accused of mercenarism. Certainly up until 2004, when Shaista Shameem replaced Enrique Bernales-Ballesteros as the UN Special Rapporteur on Mercenarism, ${ }^{138}$ the official position of the Special Rapporteur's office was that PSCs were mercenaries, ${ }^{139}$ a finding that the majority of the international community chose to reject. ${ }^{140}$ If one looks at the lax application by signatory states to PSCs of the two anti-mercenary conventions, coupled with the fact that PSCs operate in over fifty

132 Frye 2005 Fordham L Rev 2630.

133 Frye 2005 Fordham L Rev 2630.

134 Frye 2005 Fordham L Rev 2639 and 2643; aa 1, 6 OAU Mercenary Convention.

135 Cameron 2007 www.baselgovernance.org; Fallah 2006 IRRC 608.

136 Frye 2005 Fordham L Rev 2643. The UN Convention does in fact make it a crime to be a mercenary, but enforcement requires states party to the convention to legislate so as to make prosecutions possible (aa 3, 7 and 9). So unless there is domestic legislation (which at present only Italy has promulgated) in place, as there is in South Africa, it is unlikely that any PSCs engaging in mercenary activities will be prosecuted under the domestic laws of a detaining state which is party to either of the two anti-mercenary treaties.

137 Gaston 2008 Harv Int'l L J 232.

138 An office created in 1987 by the UN Commission on Human Rights.

139 UN Report 1997. Despite having said that, the report does concede that PSCs seem to "fall outside the prohibitions of international treaties and national laws banning the use of mercenaries" (Zarate 1998 Stan J Int'l L 145).

140 Cameron 2006 IRRC 575. 
states, often on government contracts, ${ }^{141}$ one gets a very particular picture. State practice and opinio juris suggest that under customary international law PSCs are not considered mercenaries for want of state practice. ${ }^{142}$ International opinion seems to suggest that there are significant reasons for treating PSCs and mercenaries differently. ${ }^{143}$

While neither the OAU Mercenary Convention nor the UN Mercenary Convention mentions PSCs, the UN is seeking

support towards an additional protocol to the Convention to address newer forms of mercenarism such as the activities of private military and security companies. ${ }^{144}$

Whether such a protocol will ever see the light of day is doubtful, as for the most part, those states making use of PSCs and those in which PSCs operate favour the drive towards the regulation of PSCs rather than outright prohibition. ${ }^{145}$ States seem to want to keep their options open in case the need for PSCs arises. ${ }^{146}$ In fact, in 2005 the Swiss government together with the ICRC began a drive towards promoting greater respect of $\mathrm{IHL}$ and international human rights law on the part of PSCs, lending credibility to the position that PSCs are not as a general rule regarded as mercenaries. ${ }^{147}$ As a result of this initiative, the thirty-five participating states, ${ }^{148}$ NGOs, academics and industry stakeholders supported the Montreux Document ${ }^{149}$ (a set of best practices and regulatory options) after a plenary session in September 2008. The Montreaux initiative has been endorsed by the HRC's "Report of the Working Group on the use of mercenaries as a means of violating human rights and impeding the exercise of the right of peoples to self determination". ${ }^{150}$ In the working group's report it is recommended that states establish a national register of military and security companies, and that member states define which types of activity in the

141 Gaston 2008 Harv Int'l L J 224.

142 Singer 2004 CJTL 533; Gaston 2008 Harv Int'l L J 241.

143 Gaston 2008 Harv Int'l L J 241.

144 Jacobs 2008 Strateg Rev S Afr 4.

145 Gaston 2008 Harv Int'l L J 242.

146 Cullen 2000 Conflict Trends 37.

147 Gillard 2006 IRRC 527.

148 Included here are the UK, France, China, Australia, Canada, Germany, USA, Italy, Uganda, Sierra Leone and surprisingly South Africa, amongst others.

149 ICRC 2008 www.icrc.org.

150 GA HRC. 
military and security field can and cannot be outsourced by the state to the private sector. ${ }^{151}$ Of course there are those that say that private security companies are only pursuing the path of self regulation to "boost consumer confidence". ${ }^{152}$ Whatever their motivation, it would seem that at present there is just not the legal or political will on the part of states (both weak and strong) to implement "tough legislation" on PSCs. ${ }^{153}$ In this regard the legislation aimed at PSCs introduced by South Africa is the clear exception.

Not only does state practice and opinio juris suggest that PSCs should not be labelled mercenaries, but in many ways PSCs fail to fulfill the six criteria required by the international definition of a mercenary. The first requirement for mercenarism is that PSCs must be "specially recruited locally or abroad in order to fight in an armed conflict". ${ }^{154}$ When one considers that many PSCs are contracted to work for a period of time rather than for a specific engagement, ${ }^{155}$ they will not satisfy this requirement as under the existing IHL regime "a combatant will only be considered a mercenary if he is hired for a specific and finite engagement". ${ }^{156}$ Moreover most PSCs are not recruited to fight but are contracted to provide advice; training; logistical support; or to act as bodyguards. This view is endorsed by the ICRC's commentary on the AP I, which states that military advice, training, and technical maintenance of weapons are not "mercenary activities" and do not in and of themselves amount to direct participation in hostilities. ${ }^{157}$ Moreover, there is doubt that the term "armed conflict" in this clause of the definition, as it was lifted from article 47 of the $A P$ I and transposed into the two Mercenary Conventions, applies to internal conflicts. Since the $A P$ I applies only to international conflicts and the OAU and UN Mercenary Conventions do not explicitly define the term, this leaves doubt that the OAU and UN Conventions intended their definition also to apply to internal conflicts. ${ }^{158}$ There is certainly a good case to be made for the contention that the first requirement will be satisfied only if PSCs are recruited specifically to fight in particular international armed conflicts.

151 GA HRC 18-19.

152 Carmola 2006 BJWA 164.

153 Cullen 2000 Conflict Trends 37, 39.

154 Article 47(2)(a) $A P$ I.

155 Frye 2005 Fordham L Rev 2657; Salzman 2008 Int'l L \& Politics 881.

156 Frye 2005 Fordham L Rev 2638.

157 Major 1992 GJICL 103. Sandoz "Private Security and International Law" 209.

158 Gumedze 2007 ASR 24. 
The second definitional requirement demands that PSCs must "in fact, take a direct part in the hostilities". ${ }^{159}$ In none of the relevant treaties is there an explanation of what activities might constitute direct participation in hostilities. In 2009 the ICRC published an Interpretive Guide ${ }^{160}$ on how to interpret this phrase. From our discussion above we would argue that PSCs could use force in self defence and to "protect the facilities they are guarding" without falling foul of the prohibition on direct participation. ${ }^{161}$ Similarly PSCs hired to perform "catering; construction and maintenance of bases"; ${ }^{162}$ unarmed checkpoint searches; ${ }^{163}$ or to act as "foreign advisers and military technicians"164 are never said to participate directly in hostilities. ${ }^{165}$ From the discussions above we would conclude that only when PSCs are located at single-use military sites; are employed to undertake "targeted killings"; ${ }^{166}$ are employed to operate high-tech weapons systems; or use computers to direct a weapon to strike a target remotely, ${ }^{167}$ can they be said to be participating directly in hostilities. ${ }^{168}$ As for the rest, those playing a "supportive or defensive role" would retain their civilian status. ${ }^{169}$

The third requirement is that PSCs must be motivated purely by excessive material compensation. ${ }^{170}$ It is widely accepted that PSCs are earning in excess of their military counterparts. PSCs employed in Iraq or Afghanistan can earn in the region of

159 It is interesting that the UN Mercenary Convention omits this requirement, which seems to suggest that any involvement in an armed conflict, even if it doesn't rise to the level of direct participation in hostilities would constitute mercenary behaviour (Fallah 2006 IRRC 609). This means that while PSCs might escape the mercenary label in terms of IHL and the OAU Convention, it would be easier to classify them as mercenaries under the UN Convention (that is, provided they satisfy the remaining requirements cumulatively).

160 ICRC 2009 www.icrc.org.

161 Dworkin 2004 www.crimesofwar.org.

162 Cameron 2006 IRRC 588-589.

163 Policy Brief 2008 www.hpcr.org 9.

164 Zarate 1998 Stan J Int'l L 123.

165 Faite 2008 www.icrc.org 4, Salzman 2008 Int'l L \& Politics 882; Sandoz, Swinarski and Zimmermann ICRC Commentary 579.

166 Policy Brief 2008 www.hpcr.org 9.

167 Cameron 2007 www.baselgovernance.org.

168 Gillard 2006 IRRC 6.

169 Sandoz, Swinarski and Zimmermann ICRC 57. Zarate suggests that the term mercenary "should not be applied to security contractors that are hired by legitimate governments, or by internationally recognised movements of national liberation for either training or combat support" (Zarate 1998 Stan J Int'l L 80).

170 In terms of the OAU Mercenary Convention any compensation will be sufficient. It need not be excessive. 
US $\$ 100000$ to US $\$ 200000^{171}$ a year, compared to US\$50 000 base pay for a Navy Seal or Green Beret counterpart. ${ }^{172}$ Having said that, however, there are some who argue that those UN member states who contribute to UN peacekeeping forces (aka "disguised mercenaries") ${ }^{173}$ also "do so largely for financial reasons". ${ }^{174}$ This leaves many academics questioning what kind of legal proof of such motivation would satisfy a court of law. ${ }^{175}$ Others suggest that international law needs to develop further to deal with foreign fighters whose motivation is monetary as well as ideological, the so-called "confessional mercenaries". ${ }^{176}$ All things considered, this leaves us questioning to what extent PSCs would fall foul of this definitional criterion. To our minds this is probably the one criterion that PSCs might easily satisfy (especially in the case of the OAU Mercenary Convention, which requires only compensation, not necessarily excessive compensation.) ${ }^{177}$ However, as the six criteria are cumulative, PSCs would still escape being categorised as mercenaries provided they did not satisfy the other five criteria.

The fourth requirement is an exemption of sorts for all PSCs who are nationals of a party to the conflict, or residents of a territory controlled by a party to the conflict. Paradoxically PSCs emanating from states party to the conflict (for example the US or UK in the case of Iraq) would automatically be exempt from mercenary status under the fourth criterion, ${ }^{178}$ while fellow employees of the same private security company would not enjoy this exemption as a result of their citizenship or residence alone. It seems that a very easy way round this requirement is for contracting firms to invite foreign PSCs to take up residence in a state party to the conflict prior to their deployment to the conflict zone, thereby affording them the right to claim this residency exemption.

171 Salzman 2008 Int'/ L \& Politics 885 cites figures of US\$ 20000 a month for PSCs deployed in Iraq.

172 Lytton 2006 Or Rev Int'I L 334. With figures like this being bandied about it is no wonder that the special forces of the US and UK are experiencing a "brain drain" (Salzman 2008 Int'l L \& Politics 885).

173 Frye 2005 Fordham L Rev 2615-2616.

174 Member states who contribute soldiers to a UN operation could earn $\$ 988$ per month, per soldier (Fountain 2005 Mich St J Int'l L 243).

175 Diplock Report para 7; Fallah 2006 IRRC 605, Gumedze 2007 ASR 27.

176 For example the Arab fighters employed by the Taliban (Frye 2005 Fordham L Rev 2637).

177 Article 1 OAU Mercenary Convention.

178 Gumedze 2007 ASR 28, Faite 2008 www.icrc.org 4. 
The fifth requirement, like the fourth, operates as an exemption for all PSCs who are members of the armed forces of a party to the conflict. As already discussed in some detail above, the likelihood of PSCs being incorporated into a state's armed forces is remote, ${ }^{179}$ although not completely without precedent. ${ }^{180}$ Gillard $^{181}$ suggests that the following indicators might be used to argue that PSCs have been incorporated into the state's armed forces: where there is a national law stipulating such incorporation; where PSCs are employed by the department of defence; where PSCs are subject to military disciplinary structures/a chain of command/a military hierarchy; or where PSCs wear uniforms or carry identity cards as envisaged by GC III. In most cases, however, given the reticence of states to officially incorporate PSCs into their armed forces, the majority of PSCs will not be able to rely on this exemption to escape mercenary status.

The final exemption available to PSCs seeking to avoid mercenary status comes into effect if they can show that they have "been sent by a State which is not a Party to the conflict on official duty as a member of its armed forces". ${ }^{182}$ This last exemption extends the previous criteria (of incorporation into the armed forces) to those who are sent by a state which is not party to the armed conflict. Some would argue that where a state has contracted PSCs (although not officially incorporating them into their armed forces) the contract of employment is sufficient to conclude that they are contractors of the employing state ${ }^{183}$ and entitled to claim this exemption. Ironically, an individual hired by a humanitarian NGO to assist with the delivery of civilian relief aid would not be able to claim this exemption, despite his or her laudable motives and IHL-endorsed mandate. ${ }^{184}$

In conclusion then, while it seems in theory possible for a PSC (in the context of an international armed conflict) to fulfill all of the requirements of the IHL definition of a

179 Gillard 2005 www.icrc.org 5.

180 This was in fact the case for Sandline in Papua New Guinea in 1997 and Executive Outcomes in Sierra Leone (Frye 2005 Fordham L Rev 2641; Zarate 1998 Stan J Int'I L 124). In the case of Sandline they were granted the status of "special constables" under the laws of Papua New Guinea so that they could carry out their functions (Cullen 2000 Conflict Trends 38.)

181 Gillard 2005 www.icrc.org 5.

182 Article 47(2) AP I.

183 Maogoto and Sheehy 2006 Bepress Legal Series 20; Frye 2005 Fordham L Rev 2646.

184 Gumedze 2007 ASR 29. 
mercenary, this would be unlikely. Moreover, provided PSCs refrain from any direct participation in hostilities, their activities will also not be "prohibited by recognised international norms". ${ }^{185}$ In the final analysis, PSCs will most likely be labelled civilians or "persons accompanying the armed forces". The infamous quote from Geoffrey Best regarding mercenaries is even more applicable to the situation of PSCs:

the definition of a mercenary in these instruments is so unworkable and riddled with loopholes that any mercenary who cannot exclude himself from this definition deserves to be shot - and his lawyer with him. ${ }^{186}$

Some have argued that the difficulties plaguing the international law definition of a mercenary have been of assistance to the private security industry, leaving PSCs in a "sort of legal limbo", ${ }^{187}$ rather than giving PSCs pause to consider the legality of their actions. To be fair, the provisions prohibiting mercenaries were never drafted with PSCs in mind, and this is especially true when those PSCs are employed by "recognised regimes"188 and by those very states and regional organisations which had spearheaded the IHL anti-mercenary provisions. ${ }^{189}$ If this is the legal situation in terms of $\mathrm{IHL}$ and international treaty law dealing with mercenaries, it is perplexing that South Africa has taken such an aggressive stance towards PSCs, particularly when other PSC supplier states are favouring a move towards regulation rather than outright prohibition. The effect of the FMA and its intended successor (the $P M A$ ) is to make the highly skilled ex-apartheid army personnel (who are mostly white) persona non grata inside our borders.

185 Zarate 1998 Stan J Int'I L 117.

186 Best Humanity in Warfare 374.

187 Abrisketa 2007 FRIDE Comment 7.

188 Zarate 1998 Stan J Int'l L 117.

189 Both Nigeria and Angola have employed the services of PSCs and even the OAU has considered employing Executive Outcomes for peacekeeping missions in Africa (Zarate 1998 Stan J Int'l L 117). 


\section{South Africa's anti-mercenary legislation in the light of the international law approach to mercenaries ${ }^{190}$}

Only a small number of states have taken steps to enact domestic legislation specifically aimed at regulating the PSC industry within their territory. ${ }^{191}$ Many of these instances of regulation have come about to end a state's reputation for being a recruiting ground for "dogs of war" eager to participate in dirty conflicts, coup attempts, and human rights abuses. ${ }^{192}$ In an era which witnessed the South Africanbased Executive Outcomes and Logo Logistics heavy involvement in conflict situations in Sierra Leone, Equatorial Guinea and Zimbabwe, it is not surprising that the South African government busied itself with drafting the Regulation of Foreign Military Assistance Act 15 of 1998 (FMA), which entered into force on 18 September 1998, and remains applicable to date. The FMA was "the first of its type in the world", ${ }^{193}$ and is widely regarded as adopting "unquestionably...the most hard-line 'anti-mercenary' stance in the international sphere". ${ }^{194}$ What is particularly interesting is that South Africa should choose to adopt such a tough approach on PSCs when it is party to neither the OAU nor the UN Mercenary Conventions. ${ }^{195}$ Its domestic legislation exceeds the international law obligations set out in either of the antimercenary conventions. ${ }^{196}$

190 The authors are indebted to Adv Max Du Plessis for affording us access to the Ex Parte submissions made to the president on behalf of a South African Private Security Company providing security services in Iraq.

191 The French Penal Code criminalises mercenary activity and prescribes sanctions of up to five years imprisonment or a fine of 75000 Euros. In terms of Italian Penal Law a number of offences are criminalised, including the participation of any person in an armed conflict of a state in which he/she does not reside or have relating citizenship. Switzerland's Penal Code prohibits Swiss nationals from participating in foreign military service without the approval of the Swiss Federal Council. Under Sierra Leone's National Security and Central Intelligence Act 10 of 2002 the granting of licenses to companies that are used to provide security services are regulated by government. The United States of America have several pieces of legislation applicable to PSCs, including the Military Extraterritorial Jurisdiction Act, 2000, the International Traffic in Arms Regulations, 1979 and the Arms Export Control Act 22 USC 2778.

192 Gillard 2006 IRRC 528; Drury 2009 www.dailymail.co.uk.

193 IRIN 2008 www.itinnew.org.

194 Baker and Gumedze 2007 ASR 4.

195 Singer 2006 BJWA 105; Abrisketa 2007 FRIDE Comment 2; Cullen 2000 Conflict Trends 36; Bjork and Jones 2005 TWQ.

196 Jacobs 2008 Strateg Rev S Afr 4. 
The FMA prohibits the recruitment, use, training or financing of mercenary activities, ${ }^{197}$ and defines mercenary activity as the "direct participation as a combatant in armed conflict for private gain". ${ }^{198}$ This mirrors closely the type of conduct prohibited under $A P I$ and the two Mercenary Conventions. ${ }^{199}$ The FMA, however, goes further and also prohibits the rendering of any foreign military assistance $^{200}$ without prior authorisation from the National Conventional Arms Control Committee (NCACC). ${ }^{201}$ Under the FMA, the term "foreign military assistance" includes within its ambit a range of activities including providing military assistance to a party to an armed conflict, and providing security services for the protection of individuals involved in armed conflict or their property. Excluded from the parameters of "foreign military assistance" are humanitarian or civilian activities aimed at relieving the plight of civilians in an area of armed conflict. ${ }^{202}$ Any person guilty of rendering foreign military assistance without the necessary permission or who fails to observe the conditions ${ }^{203}$ attached to that permission will be guilty of an offence and liable to a fine or a period of imprisonment or both. ${ }^{204}$

The South African approach to the PSC industry is markedly different from the response which PSCs have received from other governments. Britain, for example, has adopted an approach that "recognises the industry's positive and legitimate role globally, as well as the graphic extent of arenas in which PMCs operate". ${ }^{205}$ Britain has consequently set out options for the regulation of PSCs in a Green Paper and the British government is currently considering a way forward based on the responses to the Green Paper. ${ }^{206}$ In the USA the provision of military/defence

197 Section 2 Regulation of Foreign Military Assistance Act 15 of 1998 (FMA).

198 Section 1 (iv) FMA.

199 The UN Mercenary Convention and the OAU Mercenary Convention.

200 Section 3 FMA.

201 A person who wishes to engage in foreign military assistance has to make an application to the NCACC (s $4(1)$ or 5(1)). The committee will then consider the application and make a recommendation to the Minister of Defence on whether to accept or reject the application (s 4(2) or 5(3)). The Minister may then refuse or grant the application subject to certain conditions. The Minister may also at any time withdraw or amend any such authorisation (s 4(3)).

202 Section 1 (iii) FMA.

203 Also see $s$ 8(1). The FMA does not prescribe a maximum fine or maximum period of imprisonment for offences.

204 Section 8(1) FMA.

205 FCO 2009 www.fco.gov.uk 5.

206 Gomez del Prado 2008 www.law.wisc.edu. 
services is regulated by the US Arms Export Control Act. ${ }^{207}$ The US legislation defines "defence services" to include the provision of military advice and the training of foreign units and forces, ${ }^{208}$ thereby covering the tasks often performed by PSCs. Furthermore, the United States Department of Defence has issued directives ${ }^{209}$ that apply to contractors and their employees, including all non-US personnel who are employed by these contractors and who may have authorisation to accompany the US armed forces, once again a common practice in the PSC industry. Furthermore, the Military Extraterritorial Jurisdiction $A_{c t}{ }^{210}$ establishes federal jurisdiction over offences committed by any person employed by or accompanying the US armed forces committed outside the United States, potentially bringing PSCs squarely within the US courts' jurisdiction regardless of the fact that they might be foreign nationals and have committed their offences outside of US territory. However, owing to some definitional ambiguities this Act has been successfully utilised only once, to prosecute a contractor who was found with child pornography at the Abu Ghraib prison in Iraq. ${ }^{211}$ Most recently, in 2007, following the alleged abuses at Abu Ghraib, the scope of the Uniform Code of Military Justice ${ }^{212}$ was extended to include PSCs, and strictly prohibits any form of cruelty or oppression of prisoners. ${ }^{213}$ The US legislators have chosen to monitor and regulate the activities of PSCs while in Sierra Leone, private security companies are required to undergo an assessment before they are granted a licence ${ }^{214}$ to provide "security services" in terms of the National Security and Central Intelligence Act 10 of $2002 .{ }^{215}$ At most a company might face the revocation of its licence, but once the licence has been granted there are no further duties or penalties placed upon PSCs. ${ }^{216}$ Belgian legislation, promulgated in

207 Arms Export Control Act 22 USC 2778. This act is implemented through the International Traffic in Arms Regulations 1976 (as amended); Gomez del Prado 2008 www.law.wisc.edu.

208 FCO 2002 www.fco.gov.uk.

209 These directives inter alia authorise third-country nationals and host nation personnel to accompany US Armed Forces. See for instance Department of Defence Directive 2311.01E of 9 May 2006 (as amended) and Department of Defence 2005 www.dtic.mil.

210 Military Extraterritorial Jurisdiction Act (Public Law 106-523).

211 Gomez del Prado 2008 www.law.wisc.edu.

212 Uniform Code of Military Justice US Code Title 10 Subtitle A Part II Chapter 47.

213 Uniform Code of Military Justice US Code Title 10 Subtitle A Part II Chapter 47.

214 Foreign firms who would like to make use of Sierra Leonean employees must submit their request to the Ministry of Labour, which will provide them with suitable personnel (Gomez del Prado 2008 www.law.wisc.edu 19).

215 In this act, security services are defined as "such services connected with the security of the State as the National Security Council may determine" (Part I para 1, Part V para 19(9) National Security and Central Intelligence Act 10 of 2002); Gomez del Prado 2008 www.law.wisc.edu 19.

216 Gomez del Prado 2008 www.law.wisc.edu 19. 
2003, penalises ${ }^{217}$ the recruitment of any persons with the intent of serving in a foreign army in the territory of a foreign state, but does not prohibit law enforcement operations authorised by public law organisations to which Belgium is a party. ${ }^{218}$ No other state has adopted the hard-line approach towards PSCs which characterises the South African legislation - not even other states which are prolific suppliers of PSCs.

It is not surprising that the efficacy of South Africa's FMA has been undermined by "its lack of support by other international actors, notably the US and UK". ${ }^{219}$ Without their support South Africa has managed to prosecute only a handful of PSCs, despite there being an estimated 2000 to 4000 South African citizens working as PSCs in Iraq. ${ }^{220}$ Academics speculate that the legislation is likely "to push the industry underground", with PSCs more likely to opt for a change in citizenship in order to avoid prosecution. ${ }^{221}$ Already the legislation has forced Executive Outcomes to move its operations outside South Africa's borders, although this has not stopped it recruiting South Africans for work in Sierra Leone and Angola. ${ }^{222}$

After only a few high profile prosecutions it became clear that the FMA was flawed, and this led to the Department of Defence rushing through its replacement Act, the Prohibition of Mercenary Activities and Regulation of Certain Activities in Country of Armed Conflict Act 27 of 2006 (hereinafter the PMA). The PMA received Presidential assent in November 2007, but has yet to receive the necessary presidential proclamation and regulations to make it law. Under the PMA

2(1) No person may within the Republic or elsewhere -

(a) Participate as a combatant for private gain in an armed conflict;

(b) Directly or indirectly recruit, use, train, support or finance a combatant for private gain in an armed conflict;

(c) Directly or indirectly participate in any manner in the initiation, causing or furthering of

(i) An armed conflict;

(ii) A coup d'etat, uprising or rebellion against any government; or

217 With a maximum of a two-year prison term.

218 Gomez del Prado 2008 www.law.wisc.edu 14.

219 Gaston 2008 Harv Int'l L J 241.

220 Gaston 2008 Harv Int'l L J 241; Hodge 2006 www.slate.com.

221 IRIN 2008 www.irinnews.org.

222 Jacobs 2008 Strateg Rev S Afr 2. 
(d) Directly or indirectly perform any act aimed at overthrowing a government or undermining the constitutional order, sovereignty or territorial integrity of a state. ${ }^{223}$

Much like the FMA, the PMA provides that all forms of foreign military assistance 224 must be authorised ${ }^{225}$ if provided to a party to an armed conflict, or in a regulated country. ${ }^{226}$ Not only does the NCACC have the authority to attach conditions ${ }^{227}$ to its authorisation of any foreign military assistance, but section 9 of the PMA sets out a broad set of grounds upon which the NCACC can draw to justify its refusal of such authorisation. It can refuse authorisation if foreign military assistance:

(a) is in conflict with the Republic's obligations in terms of international law;

(b) would result in the infringement of human rights and fundamental freedoms in the territory where the assistance or service is to be rendered or the exemption granted;

(c) endangers the peace by introducing destabilising military capabilities into the region or territory where the assistance or service, or humanitarian aid, is or is likely to be, provided or rendered;

(d) would contribute to regional instability or negatively influence the balance of power in such region or territory;

(e) in any manner supports or encourages any terrorist activity or terrorist and related activities, as defined in section 1 of the Protection of Constitutional Democracy against Terrorist and Related Activities Act, 2004 (Act No 33 of 2004);

(f) contributes to the escalation of regional conflicts;

(g) in any manner initiates, causes or furthers an armed conflict, or a coup d'etat, uprising or rebellion against a government; or

(h) prejudices the Republic's national or international interests.

What is of particular concern, from an administrative law perspective, is that the wording of section 9 will make it extremely easy for the NCACC to deny an applicant the required authorisation, thereby infringing his or her constitutional right to practise a profession, without even granting him or her a hearing. Furthermore, neither the FMA nor the PMA provides any guidelines to the NCACC on how the conditions

223 Section 2 FMA.

224 The activities that form part of the provision of foreign military assistance are set out in $\mathrm{s} 3$ Prohibition of Mercenary Activities and Regulation of Certain Activities in the Country of Armed Conflict Act 27 of 2006 (PMA).

225 A person seeking such authorisation must submit an application to the NCACC, which considers the application and may refuse it or grant the application subject to such conditions as it may determine, or at any time withdraw or amend an authorisation already granted (s 7(2) PMA).

226 The NCACC can inform the National Executive that it is of the opinion that an armed conflict exists or is imminent in any country, and that it is of the opinion that such a country should be proclaimed as a regulated country. The President may then, by proclamation in the Government Gazette, proclaim any country as a regulated country for the purposes of the PMA (ss 6(1), 6(2)).

227 Section 7(2)(b) PMA. 
referred to in section 7(2) should be determined. ${ }^{228}$ Even more worrying is the possibility that at any time the NCACC may withdraw or amend its authorisation, ${ }^{229}$ exposing individuals to potential prosecution.

The net effect for South African citizens employed as PSCs is that their opportunities to seek employment abroad rest entirely in the hands of the NCACC, which not only has the power to designate the "regulated countries" but also has the right to refuse applications to provide foreign military assistance, or to set conditions for such permission and retract authorisation at any time. This leaves South African PSCs in the unenviable position of being potentially liable for prosecution for actions that IHL and anti-mercenary treaties do not prohibit, solely because of their citizenship. Moreover, their potential employers now perceive South African PSCs as a liability rather than an asset, given the bureaucratic demands, indeterminant conditions, and the looming possibility that authorisation can be retracted mid-contract. ${ }^{230}$ South African PSCs who are already enlisted in the armed forces of another country or employed as PSCs by foreign companies would be well advised to accept the citizenship or residency of that country in order to avoid the risk of prosecution by virtue of their South African citizenship. ${ }^{231}$

\section{Challenges facing the prosecution of PSCs under the FMA and future PMA}

It did not take many attempted prosecutions in terms of the FMA for the Minister of Defence to realise that the legislation was flawed. ${ }^{232}$ Richard Rouget was the first man to be charged under the FMA for "recruiting mercenaries for the conflict in the Ivory Coast". ${ }^{233}$ Rouget pleaded guilty to recruiting persons for military assistance, which included logistical support and the provision of equipment, and was fined R100 000 for contravening the FMA. On appeal the fine was reduced to R75 000 by

\footnotetext{
228 Sections 4(3), 5(3) PMA.

229 Section 7(2)(c) PMA.

230 Jacobs 2008 Strateg Rev S Afr 11.

231 Jacobs 2008 Strateg Rev S Afr 11.

232 The Minister of Defence conceded in his explanatory memorandum to the Bill that despite the fact that the FMA had been in operation for considerable time, very few prosecutions had been instituted in terms of the Act (Le Roux 2008 www.iss.co.za).

233 Jacobs 2008 Strateg Rev S Afr 11.
} 
the Pretoria High Court. ${ }^{234}$ In February 2004 Carl Alberts was arrested for alleged mercenary activities in the Ivory Coast. Alberts was sentenced to two years in jail or a fine of R20 000. However, after entering a plea bargain agreement with the National Prosecuting Authority his jail time was suspended and in the end Alberts only paid a fine of R10 000. ${ }^{235}$ In March 2004, only one month after Alberts had been arrested, the now infamous coup attempt in Equatorial Guinea started unfolding. Sixty-two South African citizens who were implicated in the alleged plot to overthrow the government of Equatorial Guinea were returned to South Africa in 2005 after spending a year in Zimbabwe's Chikurubi prison for immigration offences. ${ }^{236}$ Upon their return to South Africa eight of these men were charged with violating the $F M A{ }^{237}$ Crause Steyl pleaded guilty to "participating in a conspiracy to execute a coup" in Equatorial Guinea and was fined R200 000 or ten years imprisonment with a further five years suspended for five years. ${ }^{238}$ Louwrens Horn and Hermanus Carelse undertook to assist the NPA in further investigations and as a result of a plea bargain were each fined R75 000. Sir Mark Thatcher (who is by far the most prominent prosecution thus far under the $F M A)^{239}$ pleaded guilty on a lesser charge, admitting that his actions may have recklessly contributed to the financing of the coup plot. He was ordered to pay a fine of $\mathrm{R} 3$ million and received a four-year suspended sentence. ${ }^{240}$ The remaining eight accused were subject to a full prosecution in terms of the FMA (a rare occurrence) ${ }^{241}$ and all eight were acquitted $^{242}$ on the ground that the charges could not be proved. ${ }^{243}$

If one looks over the history of attempted prosecutions under the FMA it is evident that the FMA has never been thoroughly applied by the courts. ${ }^{244}$ Instead the NPA has in most cases opted for plea bargain agreements. It is telling that there has yet

234 Recently Rouget was alleged to be active in Iraq, a clear indication that his punishment under the FMA did not serve as a proper deterrent (Taljaard "Implementing South Africa's FMA" 175).

235 Taljaard "Implementing South Africa's FMA" 175, 176.

236 BBC News 2009 news.bbc.co.uk.

237 Taljaard "Implementing South Africa's FMA" 177.

238 Jacobs 2008 Strateg Rev S Afr 2.

239 Taljaard "Implementing South Africa's FMA" 179.

240 Taljaard "Implementing South Africa's FMA" 179.

241 Taljaard "Implementing South Africa's FMA" 179.

242 Case unreported.

243 Oelofse 2007 www.mg.co.za. The accused were RS Archer, V Dracula, L du Preez, E Harris, M Kashama, NT Mathias, HJ Hamman and S Witherspoon. Pretoria Regional Court Case No 14/4315/05 (unreported); Hibbitts 2007 jurist.law.pitt.edu.

244 Taljaard "Implementing South Africa's FMA" 174. 
to be a successful prosecution on the facts in terms of the FMA without a plea bargain which resulted in a guilty verdict. Some cite the potential for serious constitutional challenges to the FMA as the reason for all of the prosecutions ending in plea bargains and fines, with little or no jail time. ${ }^{245}$ Another interesting observation flowing from these attempted prosecutions is that all of the prosecutions under the FMA have been reserved for genuine mercenaries and coup plotters. To date no persons participating in what could be classified as non-mercenary security services have faced prosecution under the $F M A$. It is likely that the same difficulties regarding constitutional challenges will plague any prosecutions under the $P M A$ if it were to be rigidly applied to PSCs. If the track record of prosecutions under the $F M A$ is anything to go by, PSCs providing non-mercenary support services abroad are likely to escape prosecution, as the NPA seems to focus on traditional mercenaries and coup plotters. Although by law any PSCs engaged in unauthorised foreign military assistance are liable for prosecution, it is unlikely that the NPA will be successful in prosecuting the large number of South African citizens working abroad in this field that is, not without first overcoming some damning constitutional challenges to its legislation.

For those South African PSCs providing peaceful support services in conflict-torn regions, there is a strong case to be made that their activities (which are not criminalised under international law) are being unfairly criminalised under this domestic legislation. ${ }^{246}$ Not only is there no international law obligation upon South Africa to criminalise the actions of PSCs (provided they are not acting as mercenaries), but as we have already shown, the international community as a whole is overwhelmingly in favour of regulating rather than outlawing PSCs. The farreaching impact of the FMA will potentially have the effect of criminalising activities that were perfectly legal in the territories where they were being committed, solely because they were committed by South African citizens, permanent South African residents, or South African juristic persons. Moreover, foreign nationals who seek to recruit PSCs on South African soil without the NCACC's authorisation could find 
themselves in difficulty with the law. ${ }^{247}$ These provisions have already sent South African private security companies scampering to reinvent themselves as corporations incorporated under foreign law and located anywhere but on South African soil in order to avoid being targeted by this legislation. Moreover, South Africa has no obligation in international law to regulate the activities of South African nationals on foreign soil, or foreign nationals on South African soil, so long as their actions fall short of the international obligations to prohibit mercenary activities, and it seems clear that as international law stands at the moment PSCs are not necessarily classified as mercenaries. ${ }^{248}$ In fact, even in terms of the OAU Mercenary Convention, African states are still permitted to hire non-nationals to perform security functions, although as it stands OAU members would be well advised to avoid recruiting South African nationals, residents or juristic persons, and certainly not to carry out any recruiting on South African soil.

Another possible avenue for challenging the $F M A$ (and its successor the PMA) lies in administrative law. In terms of the FMA and the PMA any authorisation to offer foreign military assistance has to come from the NCACC. The legislation lists several grounds upon which the NCACC must refuse an application to offer foreign military assistance. $^{249}$ The difficulty which faces the NCACC in carrying out this administrative function is that these factors are broadly stated, extensive in their scope, and couched in vague terms, making it almost impossible for a potential applicant to assess the likelihood of being granted the required authorisation. South African administrative law demands that while the discretionary powers ascribed to a body (like the NCACC) may be broadly formulated, the factors relevant to the exercise of such discretionary powers must be indisputably clear. ${ }^{250}$ This is not the case with section 7 of the FMA or section 3 of the PMA. What is indisputably clear is that these vague grounds for refusing an application for authorisation will almost always provide a means of justifying the refusal of any application which the NCACC disapproves of, especially where that disapproval is motivated by private political agendas. If, as we predict, authorisation will in most instances be denied, the onus

247 See s 11(1) FMA.

248 Kaunda $v$ The President of the Republic of South Africa 20054 SA 235 (CC) Chaskalson CJ paras 38-40.

249 Section 7 FMA and s 3 PMA.

250 Dawood v Minister of Home Affairs 20003 SA 936 (CC) para 53. 
rests on the individual PSCs to request reasons from the NCACC in terms of the Promotion of Administrative Justice Act (hereafter PAJA). ${ }^{251}$ However, as correctly pointed out by Du Plessis ${ }^{252}$ in his Ex Parte submission to the president, any meaningful decision regarding an application for authorisation can be taken only after an extensive evaluation process. To this end, true administrative justice could be achieved only if each applicant were permitted to make representations to convince the NCACC that his application would not infringe any of the grounds set out in section 9 of the Bill. Regretfully this audience with the NCACC is not granted by the legislation at the time when the application is under consideration. This leaves an unsuccessful applicant burdened unnecessarily with having to rely on PAJA and the courts to challenge unfair administrative decisions. Where PSCs are sought on short notice to respond to an unfolding humanitarian disaster (post conflict), the bureaucratic delay in getting the necessary NCACC authorisation as a result of the over-reaching impact of the legislation will almost always mean that non-South African citizens will be favoured.

With the potential for the NCACC to readily deny authorisation, or at least to force PSCs to make use of PAJA to challenge an unsuccessful application, comes the real concern that these decisions by the NCACC will necessarily impact negatively on the individual PSC's right to choose their trade, occupation or profession freely as set out in section 22 of the Constitution. ${ }^{253}$ In terms of the Constitution, a South African citizen's choice of trade, occupation or profession may be regulated only by a law that is reasonable and justifiable and rationally connected to a legitimate government purpose. ${ }^{254}$ Unfortunately the implementation of the FMA (and soon the PMA) will potentially prohibit a whole range of noble activities which are currently carried out by PSCs. The vague terms in which the legislation is couched might deny authorisation to both the traditional "mercenary" and the PSCs who are employed to guard vulnerable NGOs providing humanitarian assistance in war-torn regions. Likewise, the PSCs who are involved in legitimate de-mining operations in war-torn regions

251 Promotion of Administrative Justice Act 3 of 2000 (PAJA); s 7(5) PMA provides that any person that feels aggrieved by the decision taken about his application may apply for written reasons as provided for in PAJA.

252 See note 191 above.

253 Section 22 of the Constitution of the Republic of South Africa, 1996.

254 Affordable Medicines Trust $v$ Minister of Health 20063 SA 247 (CC) para 74. 
might be tarred with the same brush as the coup plotters. These potentially absurd consequences speak to the vague, arbitrary, unreasonable and unjustifiable manner in which the FMA and future PMA impact on the constitutional rights of PSCs. Moreover, it is difficult to imagine how prohibiting their assistance in projects aimed at restoring human rights and ameliorating civilian suffering can be connected to any legitimate government purpose. Rather, it is widely recognised that civilian security services and humanitarian assistance training are essential for post-conflict reconstruction, and may be vital to protect and restore human rights in countries affected by conflict.

The $F M A$, and its successor the PMA face a myriad of constitutional, administrative law and international law challenges should they ever be actively pursued in a court, rather than being used to coerce plea bargains, as has been the experience to date. Perhaps these obstacles have catalysed the newest initiative (in terms of amendments to the South African Citizenship Act) ${ }^{255}$ planned by the government to eradicate the problem of the politically embarrassing yet burgeoning South African private security industry.

\section{Denying Citizenship to PSCs: enforcing the FMA and future PMA through other avenues}

In 2010 the South African government announced a proposed amendment to section $6^{256}$ of the South African Citizenship Act. ${ }^{257}$ The proposal permits the government to revoke the citizenship of any South African serving in a foreign military for "engaging in a war under the flag of a country that the Government of South Africa does not support". ${ }^{258}$ The concept of a "foreign military" is not defined in the Bill, but could conceivably apply to South African PSCs who are contracted to assist the armed forces of a foreign state. ${ }^{259}$ According to the Department of Home Affairs Director

255 South African Citizenship Act 88 of 1995.

256 South African Citizenship Amendment Bill B[17-2010].

257 The South African Citizenship Amendment Act will add subsection (c) to the already existing s 6 of the South African Citizenship Act.

258 DefenceWeb 2010 www.defenceweb.co.za.

259 This bill would, however, not have any effect on South African PSCs who are not serving in a foreign military. 
General, Mkuslei Apleni, this amendment is aimed only at naturalised South African citizens (i.e. immigrants), but there is nothing in the proposed amendment which shows that these provisions will not also be applied to non-immigrant citizens. ${ }^{260}$ The potential consequences for this proposed amendment could have far-reaching effects for many PSCs currently serving abroad under contracts to foreign armies. It is not clear which specific conflicts will attain the status of a war that "the Government of the Republic does not support". So, for example, a South African citizen employed as a PSC in Palestine acting as a bodyguard to Israeli government officials might find himself not only sought for prosecution under the $F M A$, but facing the revocation of his South African citizenship. As a result of the potential fall-out from this proposed amendment, Paul Boateng, in his capacity as High Commissioner for the UK Foreign Office, lobbied the South African government to ensure that the 800 plus South Africans who are part of the British army were not forced to renounce their South African citizenship. ${ }^{261}$ The ANC government rejected the petition, stating that such a provision would "create loopholes allowing South Africans not only to join foreign armies but also become mercenaries with companies such as Aegis". ${ }^{262} \mathrm{We}$ wait with bated breath to see what will become of the proposed bill, which has already drawn condemnation from the private security industry and legal academics alike.

Given the poor track record of successful prosecutions of PSCs under the FMA and the likelihood that its successor the PMA will face the same legal difficulties, it seems that this new initiative aimed at PSCs is simply a new way for South Africa to rid itself of its pesky international reputation as a fertile hunting ground for those seeking "guns for hire".

260 DefenceWeb 2010 www.defenceweb.co.za.

261 Drury 2009 www.dailymail.co.uk.

262 Paul Boateng quit his position as a British MP to become a director of Aegis Defence Services (at the centre of the "arms to Sierra Leone" scandal in 1998) (Oliver 2009 www.timesonline.co.uk). 


\section{$7 \quad$ Conclusion}

One of the unique features which differentiate present-day armed conflicts from their predecessors is the pivotal role played by PSCs. We feel it is imperative to analyse the role played by PSCs in armed conflicts and begin to theorise how IHL might respond to this new animal. To this end we have argued that those few PSCs who are officially incorporated into the armed forces of a state should enjoy primary combatant status, although state practice shows that this is an unlikely occurrence. In instances where PSCs are contracted by states to assist their armed forces and provide non-lethal services, we propose that they be categorised with those "persons accompanying the armed forces" for the purposes of IHL. As for the rest, we conclude that they will be categorised as civilians, and provided they do not participate directly in hostilities and restrict their activities to defensive ${ }^{263}$ guarding of civilian sites, they cannot be targeted or labelled as unlawful belligerents.

There is a great deal of public sentiment, fuelled by media reports of coup attempts, which has, perhaps unfairly, seen all PSCs labelled as mercenaries. Our exploration of both IHL and the two Mercenary Conventions reveals that while it seems in theory possible for a PSC (in the context of an international armed conflict) to fulfill all of the requirements of the $\mathrm{IHL}$ definition of a mercenary, this is unlikely. Consequently we conclude that the label "mercenary" is not particularly useful in devising a legal regime that can deal with the presence of PSCs in modern armed conflicts.

Within this legal framework it is perplexing that South African legislation has taken such an aggressive stance towards PSCs. The aggressive overreaching legislation has vested the NCACC with very broad grounds upon which to refuse, retract or set restrictive conditions for any PSC seeking authorisation to work abroad. Not only are these requirements particularly onerous for South African PSCs, but they are not

263 Some academics like Schmitt (Schmitt 2004 Chi J Int'l L 541 and Schmitt 2005 Chi J Int'l L 529) argue that any participation in hostilities (offensive or defensive) strips PSCs of their essentially civilian status and renders them unlawful belligerents. We have argued that a more nuanced analysis might allow for PSCs to retain their civilian status provided they limit their participation to the defence of purely civilian targets. PSCs who engage in offensive activities on the other hand, are clearly unlawful combatants, may be targeted and could face prosecution for their unlawful behaviour. 
practised by any other state, nor are they required by any international legal obligation. The net effect is to unreasonably and unjustifiably limit the constitutional right of PSCs to practise their profession, and to force South African citizens to denounce their citizenship in order to avoid prosecution. The $F M A$, and its successor the PMA, face a myriad of constitutional, administrative law and international law challenges should they ever be actively pursued in a court. We hope that debating these issues will give government pause to consider the impact of its existing legislation and expose the planned amendments to the South African Citizenship Act for what they really are - a backdoor means by which to deny the constitutional rights of the South African PSC. 


\section{Bibliography}

Abrisketa 2007 FRIDE Comment

Abrisketa J "Blackwater: Mercenaries and International Law" 2007 Oct FRIDE Comment 1-12

Baker and Gumedze 2007 ASR

Baker D and Gumedze S "Private Military/Security Companies and Human Security in Africa" 2007 16(4) ASR 1-5

Best Humanity in Warfare

Best G Humanity in Warfare: the Modern History of the International Law of Armed Conflict (Methuen \& Co Ltd London 1980)

Bjork and Jones 2005 TWQ

Bjork $\mathrm{K}$ and Jones $\mathrm{R}$ "Overcoming Dilemmas Created by the $21^{\text {st }}$ Century Mercenaries: Conceptualising the Use of Private Security Companies in Iraq" 2005 26(4\&5) TWQ 777-796

Bosch 2007 ASR

Bosch S "Private Security Contractors and International Humanitarian Law - a Skirmish for Recognition in International Armed Conflicts" 2007 16(4) ASR 3452

Bosch 2008 CILSA

Bosch S "Private Security Contractors and State Responsibility: Are States Exempt from Responsibility for Violations of Humanitarian Law Perpetrated by Private Security Contractors?" 2008 CILSA 353-382

Brooks 2000/1 Conflict Trends

Brooks D "Write a Cheque, End a War: Using Private Military Companies to End Africa's Conflicts" 2000/1 Jun Conflict Trends 33-35 
Cameron 2006 IRRC

Cameron L "Private Military Companies: Their Status Under International Humanitarian Law and its Impact on their Regulation" 2006 IRRC 573-598

Carmola 2006 BJWA

Carmola K "It's All Contracts Now: Private Military Firms and a Clash of Legal Culture" 2006 BJWA 161-173

Clapham 2006 IRRC

Clapham A "Human Rights Obligations of Non-State Actors in Conflict Situations" 2006 IRRC 491-523

Cullen 2000 Conflict Trends

Cullen P "Keeping the New Dog of War on a Tight Leash: Assessing Means of Accountability for Private Military Companies" 2000 Jun Conflict Trends 36-39

Fallah 2006 IRRC

Fallah K "Corporate Actors: The Legal Status of Mercenaries in Armed Conflict" 2006 IRRC 599-611

Fleck "Introduction"

Fleck D "Introduction" in The Handbook of Humanitarian Law in Armed Conflict (Oxford University Press Oxford 1995) xi-xv

Fountain 2005 Mich St J Int'l L

Fountain F "A Call for "Mercy-naries": Private Forces for International Policing" 2005 Mich St J Int'l L 227-260

Frye 2005 Fordham L Rev

Frye $\mathrm{E}$ "Private Military Firms in the New World Order: How Redefining 'Mercenary' can Tame the 'Dogs of War'" 2005 Fordham L Rev 2607-2664 
Gasser "Protection of the Civilian Population"

Gasser HP "Protection of the Civilian Population" in Fleck D (ed) The Handbook of Humanitarian Law in Armed Conflict (Oxford University Press Oxford 1995) 209-292

Gaston 2008 Harv Int'l L J

Gaston E "Mercenarism 2.0? The Rise of the Modern Private Security Industry and its Implications for International Humanitarian Law Enforcement" 2008 Harv Int'l L J 221-248

Gillard 2006 IRRC

Gillard EC "Business Goes to War: Private Military/Security Companies and International Humanitarian Law" 2006 IRRC 525-572

Gumedze 2007 ASR

Gumedze S "Towards the Revisions of the 1977 OAU/AU Convention on the Eliminations of Mercenarism in Africa" 2007 16(4) ASR 22-33

Henckaerts and Doswald-Beck (eds) Customary International Humanitarian Law Henckaerts JM and Doswald-Beck L (eds) Customary International Humanitarian Law (Cambridge University Press Cambridge 2005)

Holmqvist 2005 SIPRI

Holmqvist C "Private Security Companies: The Case for Regulation" 2005 SIPRI 1-66

Hough 2007 ASR

Hough L "A Study of Peacekeeping, Peace-enforcement and Private Military Companies in Sierra Leone" 2007 16(4) ASR 8-21 
Ipsen "Combatants and Non-combatants"

Ipsen K "Combatants and Non-combatants" in Fleck D (ed) The Handbook of Humanitarian Law in Armed Conflict (Oxford University Press Oxford 1995) 65-104

Jacobs 2008 Strateg Rev S Afr

Jacobs P "South Africa's new counter-mercenary law" 2008 Strateg Rev S Afr $1-17$

Kritsiotis 1998 Fletcher F World Aff

Kritsiotis D "Mercenaries and the Privatization of Warfare" 1998 22(2) Fletcher F World Aff 11-26

Kwakwa 1990 HICLR

Kwakwa E "The Current Status of Mercenaries in the Law of Armed Conflict" 1990 HICLR 67-92

Lombardi 2004 ABAJ

Lombardi C "Law Curbs Contractors in Iraq" 200414 May ABAJ 3

Lytton 2006 Or Rev Int'I L

Lytton C "Blood for Hire: How the War in Iraq has Reinvented the World's Second Oldest Profession" 2006 Or Rev Int'l L 307-335

Major 1992 GJICL

Major MF "Mercenaries and International Law" 1992 GJICL 103-150

Maogoto and Sheehy 2006 Bepress Legal Series

Maogoto JM and Sheehy B "Contemporary Private Military Firms under International Law: An Unregulated 'Gold Rush'" 2006 Bepress Legal Series 245-269 
Oeter S "Methods and Means of Combat"

Oeter S "Methods and Means of Combat" in Fleck D (ed) The Handbook of Humanitarian Law in Armed Conflict (Oxford University Press Oxford 1995) 105-208

Pictet Geneva Conventions

Pictet J The Geneva Conventions of 1949: Commentary IV Geneva Convention (ICRC Geneva 1952)

Salzman 2008 Int'l L \& Politics

Salzman Z "Private Military Contractors and the Taint of a Mercenary Reputation" 2008 Int'l L \& Politics 853-892

Sandoz "Private Security and International Law"

Sandoz $\mathrm{Y}$ "Private Security and International Law" in Cilliers $\mathrm{J}$ and Mason $\mathrm{P}$ (eds) Peace, Profit or Plunder?: The Privatisation of Security in War-torn African Societies (Institute for Security Studies Pretoria 1999) chapter 10

Sandoz, Swinarski and Zimmermann ICRC Commentary

Sandoz Y, Swinarski C and Zimmermann B (eds) ICRC Commentary on the Additional Protocol of 8 June 1977 to the Geneva Convention of 12 August 1949 (Martinus Nijhoff Leiden 1987)

Schmitt 2004 Chi J Int'I L

Schmitt M "Humanitarian law and direct participation in hostilities by private contractors or civilian employees" 2004 Chi J Int'l L 511-546

Schmitt 2005 Chi J Int'I L

Schmitt M "War, international law and sovereignty: re-evaluating the rules of the game in a new century: humanitarian law and direct participation in hostilities by private contractors or civilian employees" 2005 Chi J Int'l L 511541 
Singer 2004 CJTL

Singer P "War, Profits and the Vacuum of Law: Privatized Military Firms and International Law" 2004 CJTL 521-549

Singer 2006 BJWA

Singer P "Humanitarian Principles, Private Military Agents: Implications of the Privatised Military Industry for the Humanitarian Community" 2006 BJWA 105121

Singer Corporate Warriors

Singer P Corporate Warriors: The Rise of the Privatised Military Industry (Cornell University Press New York 2003)

Taljaard "Implementing South Africa's FMA"

Taljaard $\mathrm{R}$ "Implementing South Africa's Regulation of Foreign Military Assistance Act" in Bryden A and Caparini M (eds) Private Actors and Security Governance (Transactions Publishers London 2006) chapter 9

Walker and Whyte 2005 ICLQ

Walker C and Whyte D "Contracting Out War? Private Military Companies, Law and Regulation in the United Kingdom" 2005 ICLQ 651-689

Wright and Brooke 2007 ASR

Wright $\mathrm{D}$ and Brooke $\mathrm{J}$ "Filling the Void: Contractors as Peacemakers in Africa" 2007 16(4) ASR 105-110

Zarate 1998 Stan J Int'l L

Zarate $\mathrm{J}$ "The Emergence of a New Dog of War: Private International Security Companies, International Law and the New World Disorder" 1998 Stan J Int'I $L 75-162$ 


\section{Register of legislation}

\section{Sierra Leone}

National Security and Central Intelligence Act 10 of 2002

\section{South Africa}

Constitution of the Republic of South Africa, 1996

Prohibition of Mercenary Activities and Regulation of Certain Activities in the Country of Armed Conflict Act 27 of 2006 (PMA)

Promotion of Administrative Justice Act 3 of 2000 (PAJA)

Protection of Constitutional Democracy against Terrorist and Related Activities Act 33 of 2004

Regulation of Foreign Military Assistance Act 15 of 1998 (FMA)

South African Citizenship Act 88 of 1995

\section{United States}

Arms Export Control Act 22 USC 2778

International Traffic in Arms Regulations, 1976 (as amended)

Military Extraterritorial Jurisdiction Act, 2000 (Public Law 106-523)

Uniform Code of Military Justice US Code Title 10 Subtitle A Part II Chapter 47

\section{Register of government publications}

\section{South Africa}

South African Citizenship Amendment Bill [B17-2010]

South African Citizenship Amendment Bill [B17-2010]: GN 681 in GG 33356 of 5 July 2010

\section{United Kingdom}

Diplock Report

Report of the committee of privy counsellors appointed to inquire into the recruitment of mercenaries (Diplock Report) 1976 


\section{Register of treaties and international documents/resolutions}

Additional Protocol I (AP I)

Protocol Additional to the Geneva Conventions of 12 August 1949, and

Relating to the Protection of Victims of International Armed Conflicts 1125 UNTS 1979 1391-441

Additional Protocol II (AP II)

Protocol Additional to the Geneva Conventions of 12 August 1949, and Relating to the Protection of Victims of Non-International Armed Conflicts 1125 UNTS 1979 609-699

Geneva Convention I (GC I)

Geneva Convention for the Amelioration of the Condition of the Wounded and Sick in Armed Forces in the Field of 12 August 194975 UNTS 1950 31-83

Geneva Convention III (GC III)

Geneva Convention Relative to the Treatment of Prisoners of War of 12 August 194975 UNTS 1950 135-285

Geneva Convention IV (GC IV)

The Geneva Convention Relative to the Protection of Civilian Persons in Time of War 194975 UNTS 1950 287-417

Hague $V$

The Convention (V) Respecting the Rights and Duties of Neutral Powers and Persons in Case of War on Land 1907 (Hague V) 2 AJIL 1908 Supplement 1117-27

OAU Mercenary Convention

The Convention for the Elimination of Mercenarism in Africa 1977 OAU CM/817 (XXXIX) Annex II Rev. 3 
UN Mercenary Convention

International Convention Against the Recruitment, Use, Financing and Training of Mercenaries 19892163 UNTS 75 A/RES/44/34

\section{Register of United Nations reports and resolutions}

GA HRC

GA HRC $10^{\text {th }}$ session (agenda item 3) 21 January $2009 \mathrm{~A} / \mathrm{HRC} / 10 / 14$ at 6

GA Res 2625

GA Res 2625 UN GAOR 23 $3^{\text {rd }}$ session Supp No 18 at 5 UN Doc A/2718 1968

GA Res 3103

GA Res 3103 UN GAOR $6^{\text {th }}$ Comm 28th session Supp No 30 at 142 UN Doc A/9030 1973

SC Res 289

SC Res 289 UN SCOR $25^{\text {th }}$ session $1558^{\text {th }} \mathrm{mtg}$ at 13 UN Doc s/Res/ 289 1970

UN Report 1997

UN Report "On the Question of the Use of Mercenaries as a Means of Violating Human Rights and Impeding the Exercise of the Right of Peoples to Self Determination" 1997 UN doc E/CN4/1997/24

UN Report 2005

UN Report "The Third Meeting of Experts on Traditional and New Forms of Mercenary Activity" 2005 UN Doc E/CN4/2005/23 


\section{Register of cases}

Affordable Medicines Trust v Minister of Health 20063 SA 247 (CC)

Dawood v Minister of Home Affairs 20003 SA 936 (CC)

Kaunda $v$ The President of the Republic of South Africa 20054 SA 235 (CC)

Pretoria Regional Court Case No. 14/4315/05 (Unreported)

\section{Register of internet sources}

Abrhams 2008 privatesecurityregulation.net

Abrhams D 2008 Brief Legal Commentary on PMSCs in South Africa privatesecurityregulation.net [date of use 15 Nov 2010]

Ahmadou and Gumedze 2008 www.iss.co.za

Ahmadou N and Gumedze S 2008 Seminar Report on The Prohibition of Mercenary Activities and Regulation of Certain Activities in Areas of Armed Conflict Act 27 of 2006 www.iss.co.za/uploads/RPSSREPFIN.PDF [date of use 10 Dec 2010]

Amnesty International Date Unknown www.amnestyusa.org

Amnesty International Date Unknown Private Military Contractors: Questions and Answers www.amnestyusa.org/business/pmc/HousePartyToolKit.pdf [date of use 13 Aug 2010]

BBC News 2009 news.bbc.co.uk

BBC News 2009 Timelime: Equatorial Guinea Coup Plot news.bbc.co.uk/2/hi/africa/4170589.stm [date of use 15 Feb 2011]

Beyani and Lilly 2001 www.ssrnetwork.net

Beyani C and Lilly D 2001 Regulating Private Military Companies: Options for the UK Government www.ssrnetwork.net/uploaded_files/3542.pdf [date of use 20 Sep 2010] 
Brooks 2002 www.ipoaonline.org

Brooks D 2002 Protecting people: The PMC potential: Comments and Suggestions for the UK Green Paper on Regulating Private Military Services www.ipoaonline.org [date of use 17 Sep 2010]

Cameron 2007 www.baselgovernance.org

Cameron L 2007 International Humanitarian Law and the Regulation of Private Military Companies www.baselgovernance.org/fileadmin/docs/pdfs/Nonstate/Cameron.pdf [date of use 20 Aug 2010]

DefenceWeb 2010 www.defenceweb.co.za

DefenceWeb 2010 SA to strip soldiers abroad of citizenship? www.defenceweb.co.za [date of use 10 Dec 2010]

Department of Defence 2005 www.dtic.mil

Department of Defence 2005 Instruction 3020.41: Contractor personnel authorised to accompany the US armed forces www.dtic.mil/whs/directives/corres/pdf/302041p.pdf [date of use 1 Sep 2010]

Drury 2009 www.dailymail.co.uk

Drury I 'Ex-Cabinet Minister Paul Boateng becomes a director of a private military firm after lobbying to water down anti-mercenary legislation' Mail Online 9 November 2009 www.dailymail.co.uk [date of use 13 Oct 2010]

Dworkin 2004 www.crimesofwar.org

Dworkin A 2004 Security Contractors in Iraq: Armed Guards or Private Soldiers www.crimesofwar.org/onnews/news-security.html [date of use 27 Oct 2010] 
Elsea, Schwartz and Nakamura 2004 www.opencrs.com

Elsea JK, Schwartz M and Nakamura K 2004 Private Security Contractors in Iraq: Background, Legal Status, and Other Issues www.opencrs.com/document/RL32419/ [date of use 28 Oct 2010]

Faite 2008 www.icrc.org

Faite A 2008 Involvement of Private Contractors in Armed Conflict: Implications under International Humanitarian Law www.icrc.org/web/eng/siteeng0.nsf/html/pmc-article-310804 [date of use 20 Sep 2010]

FCO 2002 www.fco.gov.uk

FCO 2002 FCO Green Paper and Annex B: Private military companies: options for regulation www.fco.gov.uk/resources/en/pdf/pdf4/fco_pdf_privatemilitarycompanies [date of use 28 Feb 2011]

FCO 2009 www.fco.gov.uk

FCO 2009 FCO Consultation Document: Consultation on Promoting High Standards of Conduct by Private Military and Security Companies (PMSCs) Internationally www.fco.gov.uk [date of use 28 Feb 2011]

Gillard 2005 www.icrc.org

Gillard E 2005 Private Military/Security Companies: the Status of their Staff and their Obligations under International Humanitarian Law and the Responsibilities of States in Relation to their Operations http://www.icrc.org/eng/assets/files/other/2005-08-expert-paper-icrc.pdf [date of use 28 Feb 2011] 
Gomez del Prado 2008 www.law.wisc.edu

Gomez del Prado JL 2008 Mercenaries, Private Military and Security Companies and International Law www.law.wisc.edu/gls/documents/ gomez_del_prado_paper.doc [date of use 5 Jan 2011]

Hibbitts 2007 jurist.law.pitt.edu

Hibbitts B 2007 South Africa court dismisses Equatorial Guinea coup plot charge jurist.law.pitt.edu/paperchase/2007/02/south-africa-court-dismissesequatorial.php [date of use 28 Nov 2010]

Hodge 2006 www.slate.com

Hodge N 'Army for Hire' Slate 31 August 2006 www.slate.com/id/2148608 [date of use 18 Nov 2010]

Human Rights Watch 2003 www.hrw.org

Human Rights Watch 2003 Backgrounder: international humanitarian law issues in a potential war in Iraq www.hrw.org/ backgrounder/arms/iraq0202003.htm [date of use 25 Oct 2010]

ICRC 2006 www.icrc.org

ICRC 2006 Privatisation of War: The Outsourcing of Military Tasks www.icrc.org/web/eng/siteeng0.nsf/htmlall/privatisation-war-230506 [date of use 15 Aug 2010]

ICRC 2008 www.icrc.org

ICRC 2008 Montreaux Document http://www.icrc.org /web/eng/siteeng0.nsf/html/montreux-document-170908 [date of use 20 Sep 2010]

ICRC 2009 www.icrc.org

ICRC 2009 ICRC's Interpretive Guide on the Notion of Direct Participation in Hostilities under International Humanitarian Law www.icrc.org/web/ 
eng/siteeng0.nsf/html/direct-participation-ihl-feature-020609 [date of use 20 Sep 2010]

IRIN 2008 www.irinnews.org

IRIN 2008 Namibia-South Africa: Private Security Firms Look to Africa for Recruits www.irinnews.org/Report.aspx?Reportid=77326 [date of use 20 Sep 2010]

IRIN 2008 www.itinnew.org

IRIN 2008 South Africa: the downside of banning mercenaries www.itinnew.org/Report.aspx?reportid=78428 [date of use 20 Sep 2010]

Le Roux 2008 www.iss.co.za

Le Roux L 2008 South African Mercenary Legislation Enacted www.iss.co.za/pgcontent.php?UID=18822 [date of use 20 Oct 2010]

Lilly 2000 www.unidir.org

Lilly D 2000 The Privatization of Peacekeeping: Prospects and Realities in Peace Keeping Evolution or Extinction? www.unidir.org/bdd/ficheperiodique.php?ref_periodique=1020-7287-2000-3-en [date of use 12 Oct 2010]

Oelofse 2007 www.mg.co.za

Oelofse LE 'Guinea Coup Accused Not Guilty' Mail and Guardian Online 23 February 2007 www.mg.co.za [date of use 20 Nov 2010]

Oliver 2009 www.timesonline.co.uk

Oliver $\mathrm{J}$ 'Lobbying row as ex-minister Paul Boateng lands defence firm job' Sunday Times 8 November 2009 www.timesonline.co.uk [date of use 20 Nov 2010] 
Palomba 2009 www.e-IR.info

Palomba J 2009 Private Military and Security Companies and the Pursuit of Legitimacy www.e-IR.info/?p=2450 [date of use 20 Oct 2010]

Parrish 2007 www.polisci.wisc.edu

Parrish R 2007 The International Legal Status of Voluntary Human Shields www.polisci.wisc.edu [date of use 25 Aug 2010]

Policy Brief 2008 www.hpcr.org

Policy Brief 2008 Private Security Companies in the Occupied Palestinian Territory (OPT): An International Humanitarian Law Perspective www.hpcr.org [date of use 29 Nov 2010]

Portfolio Committee on Home Affairs 2010 www.pmg.org.za

Portfolio Committee on Home Affairs 2010 Public hearings on the South African Citizenship Amendment Bill www.pmg.org.za/report/20100817-publichearings-south-african-citizenship-amendment-bill-b17-2010 [date of use 28 Feb 2011]

Reuters Africa 2011 af.reuters.com

Reuters Africa 2011 Is Libya's Gaddafi Turning to Foreign Mercenaries? af.reuters.com/article/chadNews/idAFLDE71N11N20110224?sp=true [date of use 28 Feb 2011]

Singer 2005 people.cas.sc.edu

Singer P 2005 Outsourcing War people.cas.sc.edu/rosati/a.singer. outsourcingwar.fa.406.htm [date of use 1 Apr 2011] 


\section{List of abbreviations}

ABAJ

AP I

AP II

AJIL

ASR

BBC

BJWA

$\mathrm{CACl}$

CC

CILSA

Chi J Int'I L

CJTL

DRC

e-IR

FCO

Fletcher F World Aff

Fordham L Rev

FRIDE

FMA

GA Res

GA HRC

GC I

GC II

GC III

GC IV

GJICL

Harv Int'I L J

HICLR

ICLQ

ICRC
American Bar Association Journal

Additional Protocol I

Additional Protocol II

American Journal of International Law

African Security Review

British Broadcasting Company

Brown Journal of World Affairs

Consolidated Analysis Center, Incorporated

Constitutional Court

Comparative and International Law Journal of South Africa

Chicago Journal of International Law

Columbia Journal of Transnational Law

Democratic Republic of Congo

e-International Relations

Foreign and Commonwealth Office

Fletcher Forum of World Affairs

Fordham Law Review

Fundación para las Relaciones Internacionales y el Diálogo

Exterior

Regulation of Foreign Military Assistance Act 15 of 1998

General Assembly Resolution

General Assembly Human Rights Council

Geneva Convention I

Geneva Convention II

Geneva Convention III

Geneva Convention IV

Georgia Journal of International and Comparative Law

Harvard International Law Journal

Hastings International and Comparative Law Review

International and Comparative Law Quarterly

International Committee for the Red Cross 
IHL International Humanitarian Law

Int'I L \& Politics

International Law and Politics

IRIN

Integrated Regional Information Network

IRRC

International Review of the Red Cross

Mich St J Int'I L

Michigan State Journal of International Law

NCACC

National Conventional Arms Control Committee

NGO

Non-governmental organisation

NPA

National Prosecuting Authority

OAU

Organisation of African Unity

Or Rev Int'I L

Oregon Review of International Law

PAJA

Promotion of Administrative Justice Act

PMA

Prohibition of Mercenary Activities and Regulation of Certain Activities in the Country of Armed Conflict Act 27 of 2006

PMSC

Private military and security contractors

POW

Prisoners of war

PSC

Private security contractor

SA

South Africa

SAS

Special Air Services

SC Res

Security Council Resolution

SIPRI

Stockholm International Peace Research Institute

Stan J Int'I L

Stanford Journals of International Law

Strateg Rev S Afr

Strategic Review for Southern Africa

TWQ

Third World Quarterly

UK

United Kingdom

UN

United Nations

UNIDAR

United Nations Institute for Disarmament Research Periodical

UNTS

United Nations Treaty Series

USA

United States of America 